Portland State University

PDXScholar

5-18-1971

\title{
An Analysis of the Ability and Achievement of Business Education Students Compared to Non- Business Education Students
}

William B. Warberg

Portland State University

Follow this and additional works at: https://pdxscholar.library.pdx.edu/open_access_etds

Part of the Business Commons, and the Education Commons Let us know how access to this document benefits you.

Recommended Citation

Warberg, William B., "An Analysis of the Ability and Achievement of Business Education Students Compared to Non-Business Education Students" (1971). Dissertations and Theses. Paper 1527. https://doi.org/10.15760/etd.1526

This Thesis is brought to you for free and open access. It has been accepted for inclusion in Dissertations and Theses by an authorized administrator of PDXScholar. Please contact us if we can make this document more accessible: pdxscholar@pdx.edu. 
AN ABSTRACT OF THE THESIS Ot William B. Wriberg for the Master of Science in Teaching in Busiress Education presented May 18, 1971.

Title: An Analys is of the Ability and Achievement of Bus iness Education Students Compared to Non-Business Eduation Students.

APPROVED BY MEMBERS OF THE THESIS COMMITTEE:
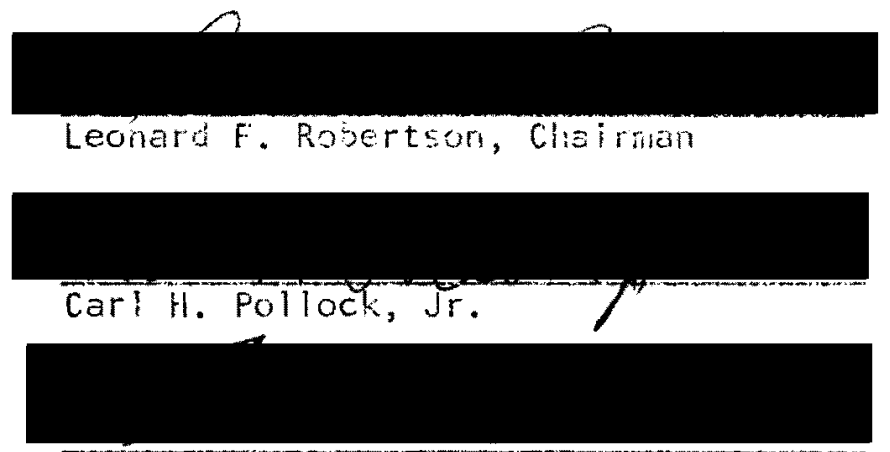

Forbes W. WilTiains

Since some educators believe the underachiever and the lowability student are frequently placed in business education classes for the purpose of finding tin an essy wey through school, this study at tempts to deternine just where the business education student actually ranks in achievement and ability as compared to students in other academic areas.

The students used in this study come from the graduating classes of 1969 and 1970 of Beaverton and Sunset High Schools in Beaverton School District 48, Beaverton, Oregon.

A business education student has been defined as one who has successfully completed at least two of the following courses: Shorthand 11; Office Techniques or Vocational office Block; Bookkeeping; and Business Law. 
A survey instrument was used to separate the business education from the non-business education students. The survey instrument records the scores of DAT (Differential Aptitude Tests) and the GPAs (grade point averages) of all students included in this study.

Mean scores were computed reflecting the DAT scores and GPAS of both groups. These mean scores reflecting the difference between the business education and non-business education students were tested to determine the level of significance.

Students included in this survey numbered 1705: $199 \mathrm{classified}$ as business education students and 1506 classified as non-business education students.

The study revealed a sharp decline in the number of students enrolled in business education in 1970, as compared to 1969.

The mean DAT score for the business education student was 56.35 as compared to 62.60 for the non-business education student. The difference of 6.25 was tested and had a critical ratio of 3.11 , which is significant at the .01 level.

The mean GPA for business education students was 2.56 as compared to 2.68 for the non-business education students. This difference of .12 was tested and had a critical ratio of .86 , which is not significant.

The reasons for the decline in the number of students enrolled in business may be: (1) the addition of new courses to the school curriculum; (2) fewer students are taking business education classes as defined by this study; and (3) business education is not as appealing as it once was because of changing business patterns. 
The fact that business exiucation students are of a lower ability might be because: (1) business education classes appeal to the lower ability student; or (2) that counselors do, in fact, use business education as a dumping ground.

Since this study revealed that the GPA of business education students nearly equals that of other students, the possibility exists that: (1) business education is more interesting than some other subjects; (2) the content of business education $\mathrm{classes}$ is less challenging; (3) less student performance is required in business education; or (4) business education attracts the overachiever.

The main purposes of this study were to: (1) provide more effective guidance and placement of students in business education; (2) provide informative data upon which to base future curriculum planning; and (3) verify or disprove the prevailing assumption that business education students are of a lower caliber. Since this study has revealed that the number of students enrolled in business education has declined and that business education students are in reality of lower ability, the results have been given to the counseling and business education departments at the schools involved. It is hoped that the results will help educators make a realistic assessment of the condition that does exists, so students can be placed and schooled in their areas of interest.

Further studies are needed to: (1) determine whether or not the decline of students enrolling in business education will continue; (2) determine if the low-ability students are being channeled into new 
courses added to the school curriculum; and (3) reveal how business education students are performing in specific academic areas.

Such studies might be of additional value to counselors through a more effective channeling of students into appropriate interest areas and careers. 
AN ANALYSIS OF THE ABILITY AND ACHIEVEMENT OF BUSINESS EDUCATION STUDEITS COMPARED TO

NON-BUSINESS EDUCATION STUDENTS

by

WILL IAM B. WARBERG

A thesis submitted in partial fulfillment of the requirements for the degree of

\author{
MASTER OF SCIENCE IN TEACHING \\ in \\ BUSINESS EDUCATION
}

Portland State University 1971 
TO THE OFFICE OF GRADUATE STUDIES:

The members of the Committee approve the thes is of William B. Warberg presented May 18, 1971.

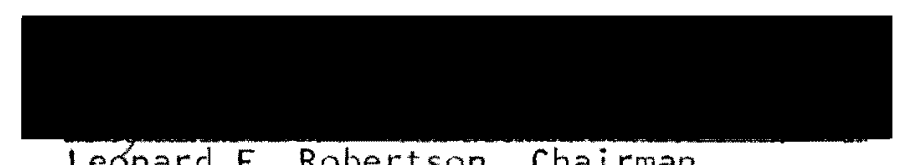

Leonard F. Robertson, Chairman
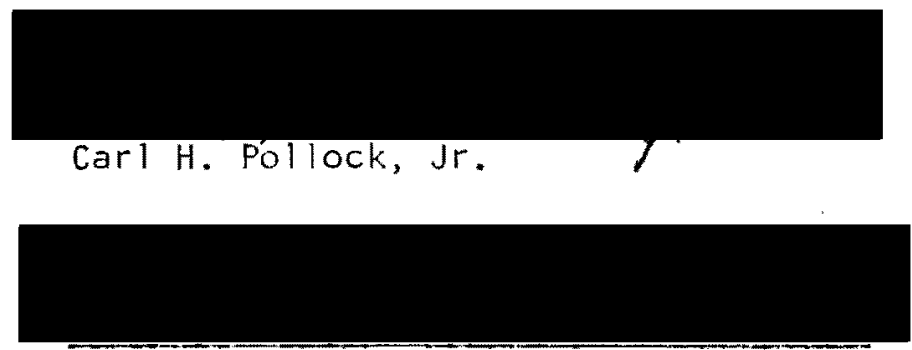

Forbes W. Williams

APPROVED :
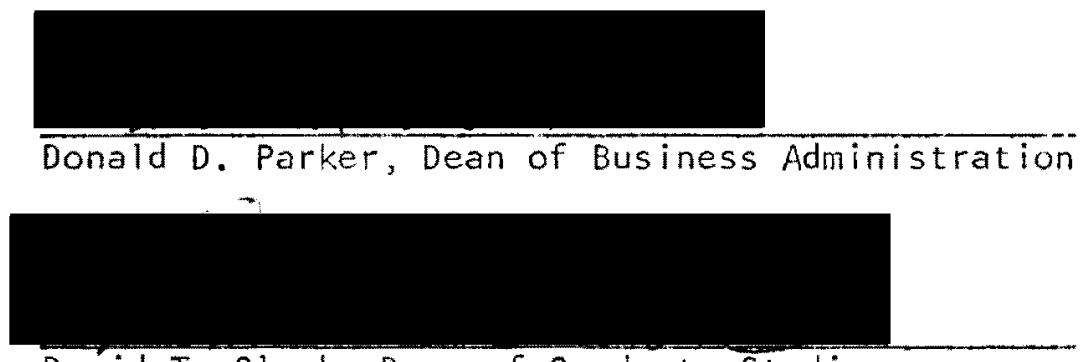

David T. Clark, Dean of Graduate Studies 


\section{ACKNOWLEDGMENTS}

I am very much indebted to Dr. Leonard F. Robertson, Chairman of the Business Education Department at Portland State University and Chairman of my thes is committee, for the time, guidance and assistance he has given in the preparation of this thesis. I have greatly benefited from his experience and advice.

I deeply appreciate the help of Dr. Carl H. Pollock, Jr., my academic advisor. His assistance in organizing my Master's program has been invaluable. His encouragements helped lead to the preparation of this thesis.

I am grateful to Dr. Forbes Williams for his time and efforts in my behalf, particularly during the early stages of my Master's degree program. His suggestions and advice led to my completion of this degree in Business Education. 
ACKNOWLEDGEMENTS ..................... i i i

LIST OF TABLES .................... . vi

CHAPTER

I INTRODUCTION ......................... 1

Statement of Problem .......... . 1

Purpose of study............. 2

Delimitations ............. 2

Definition of Terms .......... 3

summary ................... 6

II REVIEW OF RELATED LITERATURE . . . . . . . . 7

Introduction ............ 7

Interviews.............. 12

Summary .............. 13

III METHODS AND PROCEDURES ............ 15

Introduction ............ 15

Selection of Sample ........ . 15

Time Involved . . . . . . . . . . 16

Personal Contact............ 16

Survey Instrument . . . . . . . . 16

Frequency Distributions . . . . . . 17

Mean Scores ............ 17

Level of significance ......... 18 
CHAPTER

Findings . . . . . ....... 18

Summary ............. . . 19

IV PRESENTATION OF FINDINGS ........... 20

Introduction ........... 20

DAT Findings . . . . . . . . . . 21

GPA Findings............ 23

Summary ............... 25

$\checkmark$ CONCLUSIONS AND RECOMMENDATIONS ......... 27

Introduction ............. 27

Conclusions . . . . . . . . . 28

Recommendations . . . . . . . . 29

FOOTNOTES ............................ 31

BIBLIOGRAPHY . . . . . . . . . . . . . . . 32

APPENDICES . . . . . . . . . . . . . . . . . 34

A DIFFERENTIAL APT ITUDE TEST DEFINITION OF
VERBAL REASONING AND NUMERICAL ABILITY . . . . . 34

B SURVEY INSTRUMENT . . . . . . . . . . . . . 37

C FREQUENCY DISTRIBUTIONS ................ 38

D LEVEL OF SIGNIFICANCE . . . . . . . . . . 58 


\section{LIST OF TABLES}

TABLE

PAGE

1 DAT Range and Mean for the 1969 and 1970

Business Education Graduates from Beaverton and Sunset High Schools...........

11 DAT Range and Mean for the 1969 and 1970

Non-Business Education Graduates from

Beaverton and Sunset High Schools.......

III GPA Range and Mean for the 1969 and 1970

Business Education Graduates from Beaverton

and Sunset High Schools.......... 24

IV GPA Range and Mean for the 1969 and 1970

Non-Business Education Graduates from

Beaverton and Sunset High Schools ....... 


\section{CHAPTER I}

\section{INTRODUCTION}

\section{INTRODUCTION}

Some educators feel that it is the underachieving and the lowability students who drift into business education classes for the purpose of finding an easy way through school, or for the purpose of selecting an occupation in which they might be successful. It is also said that counselors often use business education classes as a dumping ground for students who cannot easily be programned into other academic areas. One way of determining whether or not these assumptions are true would be to compare the potential ability and achievenerit levels of business education students to that of students in other academic areas. This study has attempted to make such a comparison.

\section{STATEMENT OF THE PROBLEM}

This comparative study has endeavored to determine just where the business education student ranks in ability and achievement as compared to students in other academic areas.

Student abilities have been determined by averaging the scores of the Verbal Reasoning and Numerical Ability batteries of the Differential Aptitude Tests. Student achievement has been reflected by grade point averages at the end of the senior year. The 1969 and 1970 graduating classes from Beaverton and Sunset High Schools, 
Beaverton School District 48, Beaverton, Oregon, were used.

111. PURPOSE OF THE STUDY

This study was undertaken to: (1) determine the academic achievenent and potential ability of the business education student, which can aid in his guidance and counseling; (2) help in the development of future curriculum planning; and (3) either verify or disprove the prevailing assumptions that business education students are of lower ability.

\section{DELIMITATIONS}

Beaverton School District 48 is young and fastgrowing. Adjoining Portland on the east and extending to the Tualatin Valley on the west, it covers fifty-seven square miles and has a population of about 65,000

Beaverton is the fourth largest school district in Oregon. Student enrollment has $\mathrm{climbed}$ from 10,000 in 1960 (when the district was formed with the reorganization of 13 small districts) to slightly over 18,000 today.

Two high schools in the Beaverton School District have been included in the study. These are Beaverton and sunset, with a current enrollment of 1,655 and 1,633 respectively.

Students used in this survey came from the graduating classes of 1969 and 19\%0. Transfer students who moved into the district since the tenth grade were not included. 
V. DEFINITION OF TERMS

The terms used in this report which need definition are achievement, ability, DAT, GPA, and business education student.

Achievement. The accumulative grade point average upon graduation for the 1969 and 1970 graduates from Beaverton and Sunset High Schools.

Ability. Ability has been determined from the results of the Differential Aptitude Test, which was administered during the tenth grade to the 1969 and 1970 graduates from Beaverton and Sunset High Schoois.

DAT. The Differential Aptitude Tests (The Psychological Corporation, 304 East 45th Street, New York, New York 10017) are an integrated battery of standardized tests used for measuring the abilities of students in grades eight through twelve for the purpose of educational and vocational guidance. Results are reflected in national norm percentile scores. The Differential Aptitude Test (DAT) score used in this study is the average of the Verbal Reasoning and Numerical Ability Tests, which are described in Appendix $A$.

GPA. The Grade Point Average (GPA) was obtained by averaging al! grades recorded for the tenth, eleventh, and twelfth grades. Grades have been averaged on the basis of 4 points for an $A, 3$ for a $B$, 2 for a $C$, and 1 for a D.

Business Education Student. All business education students used in this survey have completed at least two of the following courses: Shorthand 11 , Office Techniques or Vocational office Block, 
Bookkeeping, and Business Law. These courses are defined as follows:

1. Shorthand 11. Students enrolling in this class must have received a grade of "C" or better in Shorthand 1. Students accepted in this course must be able to take new material dictated at 100 or 120 words per minute for a period of five minutes with a 5 -percent error limit and transcribe rapidly and correctly. They must also be able to produce mailable letters in sufficient quantity and quality to meet current office standards. Correct construction of business letters, including word usage, correct spelling and punctuation is also taught in Shorthand 11 .

2. Office Technigues or Vocational office Block. These are defined as follows:

A. Office Techniques is a vocational subject for students who have successfully completed Typewriting :, Advanced Typewriting, or Developmental Typewriting. In these courses students are taught proper grooming for business offices; office attitudes; public and human relations; alphabetic filing; copying and duplicating processes; machine transcription; telephone conversation; proficiency on at least one adding machine, as well as proficiency in the typing of business forms and letters and how to apply for jobs and interview prospective employers.

B. Vocational office Block is open to both shorthand and non-shorthand students. It is the final course in ciericalsecretarial training. Prerequisites for this class include: 
a typing speed of 35 WPM for five minutes with a 5-error limit, a knowledge of basic business letter styles and a familiarity with tabulation problems. These students must be able to type mailable business forms and letters; type mailable letters from machine transcription; operate small office machines proficiently; compose acceptable business letters; have a usable knowledge of alphabetic, geographic, and numeric filing systems; and be able to handle records management. They must also demonstrate reasonable skills in the areas of human and public relations, in data processing, and in routine work in the modern office.

3. Bookkeeping. This is a pre-vocational course introducing students to the importance and functions of systematic adequate records in modern-day business. Beginning with the financial statements of a business, the students learn a logical sequential cycle of bookkeeping procedures using the double-entry system. Students enrolled in this course are taught to keep business records, complete financial reports and maintain supplementary office records, and interrelate the bookkeeping-accounting process with mechanical and electronic data processing equipment.

4. Business Law. This course is designed to give the students an understanding of the laws which govern day-to-day business activities and an awareness of legal rights and responsibilities. These students study the laws governing contracts. They also study buying and selling, employment, principal and agent, negotiable instruments, insurance, bailments, debtor-creditor relations, real and personal property, and the various types of business organizations. 
Vi. SUMMARY

This study has attempted to determine the academic characteristics of the business education student. The DAT scores and the GPAs of business education students have been compared to those of students enrolled in other academic areas in Beaverton School District 48 , Beaverton, Oregon.

The results of this survey should be useful in the guidance and counseling of students in business education courses, and verify or disprove the assumptions that business education students are of a lower abi 1 ity. 
CHAPTER II

- RELATED LITERATURE

\section{INTRODUCTION}

Many studies have been made about teaching the underachiever, overachiever, and slow learner in business education, but apparently no studies have been done relating to the academic ability of students who take business education classes.

The review of 1 iterature has therefore concentrated generally on the types of students presently encouraged to take business education classes, and what is being accomplished with the varying acaderic types that are generally enrolled in business education courses.

Several interviews were required to help ascertain the direction of this study; these are included as part of this section.

Vast numbers of students who once dropped out of school or were eased or pushed out before graduation are now staying longer. This problem is discussed by Thomas A. Rothchild ${ }^{1}$ on how we identify and help the slow learner. At one time, there was no place in the secondary school for the slow learner, but now schools are attempting to sustain their interest, find a program of value to them, and bring them into the mainstream of secondary education.

Thomas Rothchild said that attention nust be turned to the slow learners, since they represent such a sizeable number of students new to the secondary school. In a standard population of students, 
from 15 to 20 percent would be classified as slow learners.

There is no scientific scale available for the identification of slow learners, but they can be defined as those whose general educational potential is below average but not so low as that of the educable retarded. Characteristics attributed to the slow learner identified by Rothchild are:

1. The achievement record of the slow learner is below average.

2. His reading comprehension is below average, and he is usually more than two years below grade level in reading skills and comprehension.

3. He has a shorter-than-average attention span when he is faced with traditional school work.

4. He is "now oriented" rather than "future oriented." He needs to see the present value of an activity because he thinks little of the future.

5. He is easily discouraged by traditional school work which he has faced with fallure for years.

6. He cannot handle abstractions too well.

7. He has had little to work with because, in the past, few instructional materials have been planned specifically for this type of student.

8. He does not fit well socially into the usual school pattern of extracurricular activities.

9. He does not work well when grouped with the student who tests as average or above but who is resisting his school environment.

10. He needs routine, but he also must have variaty within the routine.

11. He can learn and wants to learn, but he requires more time to achieve than does the average learner.

Rothchild states that business education must accept the challenge of providing useful school experiences specifically for the slow learner. A program would be best planned cooperatively with a sympathetic administration, which has the necessary factual data to help in identification of the slow learner and for future counseling. Joseph S. Herber ${ }^{2}$ asks if we should, in business education, accept or reject the typical slow learner, or if there is a place for 
the student who cannot compete with students of his own age. He answers this question by saying that since the slow learner is close to the drop-out line, business education must be of service, and that he should be given a fighting chance. He says that business education must prepare simple, yet practical, course objectives, then match these objectives with slow learner courses; procure one or two teachers who want to work with slow learners, and encourage counselors to cooperate by identifying true candidates.

G. Dale Meyer ${ }^{3}$ said that much too often it is the slow learner who becomes a dropout, and that the time for teachers to help such a student is long before the decision to leave the school has been made. Thus, the slow learner's identification and his difficulties must be defined and dealt with early. One of the big problems that business teachers face is that the present curriculum is not designed for the slow learner.

Meyer said that individual teachers must adapt their methods and approaches to the specific situations they face, and that the place to begin solving the slow learner's problem is in the individual teacher's mind. He also stated that business education should welcome these students in our basic business classes, and realize that too many other doors have already been closed to them.

Robert A. Schulthe is 4 said that the role of business education in the education of the slow learner is quite clear, and that business education should provide learning experiences for slow learners in general business courses. The role of business education, in terms of vocational objectives, remains uncertain because of the lack of evidence 
pertaining to their ability to retain and succeed in office positions. Schultheis also said that trecause of the ability of slow learners to secure office positions, and because of the clerical shortage, it would appear justifiable to permit and even encourage interested slow learners to enter programs which would develop their employability in low-level general office positions.

According to Milton C. $01 \operatorname{son}^{5}$, increased emphas is has been placed on the education of academically talented young people for the past few years. He said that academically talented students should be given the opportunity to study the American business and economic system in a manner appropriate to their superior talents. Some of the statements and recommendations he made are:

1. The academically talented should be exposed to a stimulating study of our business system and of the business economic principles and problems if our way of life is to persist. It is imperative that they face the world economically literate and able to think intelligently in terms of their economic surroundings.

2. Guidance personnel and teachers should make students aware of the opportunities in business, particularly in management and other higher-echelon positions when academically talented youth are involved.

3. Academically talented students should be encouraged to study those business subjects which may be of special interest or of special value to them.

4. Talented students should be grouped into special classes, or accelerated individually, whenever possible. They should conduct individual investigations, plan, and lead classroom activities, and master techniques for solving problems.

5. Talented students should study the requirements and relationships of all occupations and professions.

6. The administrating and teaching staff should keep well informed about the fields of business and business education in the overall guidance of students.

7. An identification of the fields of business and business education to academically talented students should be emphasized as a matter of vocational guidance. The encouragement of able students to consider teaching, including business teaching, should have an important place. 
8. The development of high school dual majors is recomnended. These majors should include courses for college entrance as well as for preparation for employment in busi.ness occupations.

9. All academically talented students should be encouraged to gain competency in personal-use typewriting, a universal tool of literacy. Those preparing to pursue advanced school programs in which rapid note-taking or machine computing will be helpful aids, should be given the opportunity to gain needed proficiency in these areas.

10. And finally, the business teacher should be an exceptional person and a gifted teacher, with a rich educational background in liberal arts, business, and economics.

In a symposium by Enos Perry 6 and others, questions were asked regarding what should be done with our students of lower ability and how they could earn a living in the businesses of today and tomorrow. Following are some contributions by this symposium that try to take a realistic and sympathetic point of view:

1. Enos Perry said that students of lower ability must be identified. He also said that we must 1 ist and identify the different business positions they can fill, and make practical suggestions about the suitable subjects and teaching techniques required to educate then.

2. Maxie Lee Work 7 said we must: (1) develop the stronger qualities of our less gifted students; (2) develop a desire to teach them; and (3) ceaselessly search for teaching techniques adapted to guiding their learning.

3. Dorothy Schwart $z^{8}$ said that in dealing with students of lower ability, our problem is to discover the individual's special deficiency, encourage him in his areas of normalcy, and guide him as well as possible.

4. Hazel Flood 9 said that all students should be permitted to take business courses in the secondary school if: (1) they can profit 
by the experience; (2) they are educable; (3) they want to learn;

(4) equipment is available to teach them; (5) jobs are available that

require a lesser degree of ability; and (6) the students have enough natural ability to learn vocational applications of the skilis.

5. Margaret Andrews ${ }^{10}$ said that the two keys in working with students of lower ability, who are in our schools and there to stay, are to open student potential and to open job potential.

6. Harland Sampson ${ }^{11}$ speaks for the distributive education program and said that the capacity of the distributive education program to serve students of lower ability is limited only by the adaptability of the coordinator, the availability of student training stations, and the presence of materials and facilities suited to the needs of each student.

\section{INTERVIEWS}

Since apparently little related literature pertains directly to this study, many interviews were required to ascertain the direction of the study, and to help outline the procedures. These interviews were as follows:

1. With Dr. Boyd Applegarth, Superintendent of School District 48 , Beaverton, Oregon. At this interview it was requested that Beaverton School District 48 be used for this study. Dr. Applegarth concurred, and suggested certain people to contact for obtaining information needed for the research. Dr. Applegarth also expressed a desire for School District 48 to share in the findings.

2. With Mr. Ken Box, Director of Vocational and Adult Education, and Business Education in the Beaverton Schools. Many interviews were 
held with Mr. Box to discuss the different directions of this study and to help discuss the findings.

3. With Robert Mclllroy, Director of Pupil Personnel Services in the Beaverton Schools, now at Portland State University. This interview was held to discuss the best way possible of measuring the academic achievement and ability of all students used in this study. It was decided that the best way to reflect their achievement and ability was to use their grade point averages at the end of the senior year, and the scores of DAT tests administered in the tenth grade.

4. With Melvin Wells, Ass istant Business Manager of Beaverton School District. This interview concerned the different materials included in the students' cumulative folders.

5. With Mr. Jack Boden and Mrs. Jennie Scales, teachers in the business education departments at Beaverton and Sunset High Schools. These interviews were made for the purpose of clearly defining the Business Education student. It was decided that a business education student is one who is enrolled in at least two of the business classes defined in Chapter 1 , under definition of terms.

\section{SUMMARY}

No studies were found relating to the types of students enrolled in business education. However, the various studies relating to these different types appear to reflect that much must be done to educate the slow learner, the underachiever, and the overachiever since they represent an important segment of our social structure. 
Studies relating directly to the slow learner and underachiever seem to indicate that business education departments are encouraging this type of student to enroll in business classes.

From the various interviews, much was accomplished to set up the procedures that follow in Chapter 111. 


\section{CHAPTER 111}

\section{PROCEDURES}

\section{INTRODUCTION}

This study involved the survey or status study method of investigation. It has obtained and recorded data which compared the achievement and ability of all business education students to students in other academic areas.

Procedures followed for this investigation included personal contact with the principals and guidance counselors at each of the respective schools, and a survey instrument was used to record the DAT, GPA and business classes completed. This information was obtained from the cumulative folders, which are compilations of each student's records upon graduation.

From the survey instrument, frequency distributions were prepared for each graduating class, separating the business and non-business education students' GPA and DAT scores. A mean score was computed for each frequency distribution. The level of significance was determined on the bas is of the difference between the business and ron-business education students' mean DAT scores and GPAs.

\section{SELECTION OF SAMPLE}

The 1705 students from the graduating classes of 1969 and 1970 from Sunset and Beaverton High Schools, Beaverton School District 48, 
Beaverton, oregon were included in this study. This excludes those students who did not take the DAT test.

\section{TIME INVOLVED}

The total time involved for this study was approximately one year.

\section{PERSONAL CONTACT}

Each principal and guidance counselor at the respective schools was contacted prior to the survey. This was done to assure participation and to fully explain the purpose of the study, the procedure to be followed, and what was to be accomplished from the research. Arrangements were made, and a schedule was set up reflecting the most suitable times to obtain the data from the cumulative records. Since these cumulative folders were in the school vaults, special arrangements had to be made for reviewing them outside of regular school hours.

\section{SURVEY INSTRUMENT}

A survey instrument was used to obtain the information needed for this study. The survey instrument (Appendix B) includes the following information:

1. Business student: This reflects whether or not he is a business student as identified in Chapter 1.

2. Business classes completed: This reflects the business classes completed, and thus identifies an individual as a business education student. 
3. DAT: This reflects an average of the verbal reasoning and numerical reasoning abilities from the Differential Aptitude Tests as defined in Chapter 1. This DAT score is used for both business and non-business students.

4. GPA: This reflects the grade point mean of both business and non-bus iness students.

\section{FREQUENCY DISTRIBUTIONS}

Frequency distributions were used which reflect the following information:

1. The class intervals.

2. The frequency distribution of DAT scores and GPAs in the appropriate class interval.

3. A deviation value for each class interval from an assumed mean which has a deviation value of zero.

4. An fd value, which is obtained by multiplying each class interval by the corresponding deviation value. This column is then totaled to get a figure which is used in computing the mean scores.

5. The total number of cases represented by the table.

\section{MEAN SCORES}

Following each frequency distribution, a mean score was computed from the following formula.

$$
M=A S M+\frac{(\varepsilon f d)}{N} i
$$

$$
\begin{aligned}
M & =\text { Mean } \\
\text { ASM } & =\text { Assumed Mean } \\
\varepsilon f d & =\text { Summation of the fd value } \\
\mathbf{i} & =\text { Interval } \\
N & =\text { Total Number of Frequencies }
\end{aligned}
$$


VIII. LEVEL OF SIGNIFICANCE

In order to determine if the findings were valid, it was necessary to evaluate the difference between the business and non-bus iness education students' GPAs and DAT scores. To accomplish this, the level of significance was determined from the following formula:

$$
\begin{aligned}
t & =\frac{M 1-M 2}{\sqrt{\frac{S 1^{2}}{N 1}+\frac{S 2^{2}}{N 2}}} \\
t & =\text { Level of Significance } \\
M & =\text { Mean } \\
S & =\text { Standard Deviation } \\
N & =\text { Number of Frequencies }
\end{aligned}
$$

\section{FINDINGS}

It is hoped the findings will be beneficial to all concerned in the scheduling and placement of students, including teachers, counselors and educators in general.

The findings include data on the DAT scores and GPAs, which compares individually and compositely the four graduating classes involved in this study, and includes the following information:

1. The class and number of students involved.

2. The range and mean DAT score of business and non-business students used in the survey.

3. The range and mean GFA of business and non-business students, 4. The percent of the graduation class that this data represents. 


\section{SUMMARY}

All graduates from the classes 1969 and 1970 included in this stury were classified as business education or non-business education students. Their DAT scores and GPAs have been recorded and tabulated to reflect the mean DATs and GPAs of each group. The findings of each group were compared. The implications of this comparative study are presented in the final chapter. 
CHAPTER IV

FINDINGS

\section{INTRODUCTION}

The data presented in this chapter compares the ability and achievement of the business education student to the ability and achievement of the non-business education student. DAT scores and GPAs were recorded on a survey instrument, from the information contained in the cumulative folders of the 1969 and 1970 graduates from Beaverton and Sunset High Schools of Beaverton School District 48 .

From this data, frequency distributions were prepared (Appendix C) for the DAT scores and GPAs and reflect:

1. The different schools and graduating classes.

2. The business education students and the non-business education students.

3. A composite of all business education students' DAT scores and GPAS .

4. A composite of all non-business education students' DAT scores and GPAs.

A mean score has been computed for each frequency distribution. The level of significance (Appendix D) has been determined on the basis of the difference between the business education and nonbusiness education students' mean DAT scores and GPAs. 


\section{DAT FINDINGS}

The following data separates the business education students from the non-business education students and reflects:

1. The number of students in each graduating class as well as the total number of students included in each group.

2. The DAT range in each graduating class as well as for the total group.

3. The mean DAT score for each graduating class and the total mean score for each group.

4. The percent of students that the data represents.

TABLE 1

DAT RANGE AND MEAN FOR THE 1969 AND 1970

BUSINESS EDUCATION GRADUATES FROM

BEAVERTON AND SUNSET

HIGH SCHOOLS

\begin{tabular}{|c|c|r|r|c|c|}
\hline \multirow{2}{*}{$\begin{array}{c}\text { Graduating } \\
\text { Class }\end{array}$} & \multicolumn{1}{|c|}{$\begin{array}{c}\text { No. of } \\
\text { Students }\end{array}$} & \multicolumn{2}{|c|}{$\begin{array}{c}\text { DAT Range } \\
\text { From }\end{array}$} & $\begin{array}{c}\text { Mean DAT } \\
\text { Score }\end{array}$ & $\begin{array}{c}\text { Percent } \\
\text { of Class }\end{array}$ \\
\hline 1969 BHS & 63 & 12 & 97 & 59.05 & 13.3 \\
\hline 1969 SHS & 66 & 2 & 97 & 52.15 & 15.7 \\
\hline 1970 BHS & 27 & 12 & 97 & 62.95 & 6.7 \\
\hline 1970 SHS & 43 & 7 & 97 & 54.65 & 10.6 \\
\hline Total & 199 & 2 & 97 & 56.35 & 11.7 \\
\hline
\end{tabular}


TABLE II

DAT RANGE AND MEAN FOR THE 1969 AND 1970

NON-BUSINESS EDUCATION GRADUATES

FROM BEAVERTON AND SUNSET

HIGH SCHOOLS

\begin{tabular}{|c|r|r|r|r|c|}
\hline $\begin{array}{c}\text { Graduat ing } \\
\text { Class }\end{array}$ & \multicolumn{1}{|c|}{$\begin{array}{c}\text { No. of } \\
\text { Students }\end{array}$} & \multicolumn{2}{|c|}{$\begin{array}{c}\text { DAT Rarge } \\
\text { From }\end{array}$} & $\begin{array}{c}\text { Mean DAT } \\
\text { Score }\end{array}$ & $\begin{array}{c}\text { Percent } \\
\text { of Class }\end{array}$ \\
\hline 1969 BHS & 410 & 2 & 97 & 63.30 & 86.7 \\
\hline 1969 SHS & 354 & 2 & 97 & 60.00 & 84.3 \\
\hline 1970 BHS & 376 & 2 & 97 & 64.05 & 93.3 \\
\hline 1970 SHS & 366 & 2 & 97 & 62.65 & 89.4 \\
\hline Total & 1506 & 2 & 97 & 62.60 & 88.3 \\
\hline
\end{tabular}

In 1969 there were 63 business education students and 410 nonbusiness education students in Beaverton High School, and 66 business education students and 354 non-business education students in Sunset High School.

In 1970 there were 27 business education students and 376 nonbus iness education students in Beaverton High School, and 43 business education and 366 non-business education students in Sunset High School.

There were 199 business education students and 1506 non-bus iness education students for a total of 1705 students in this study.

The DAT range was from 2 to 97 for both the business education and non-business education students. The mean CAT score for the 
business education student was 56.35 as compared to 62.60 for the nonbusiness education student. The difference of 6.25 was tested (Appendix D) and had a critical ratio of 3.11 , which is significant at the .01 level.

The 199 business education students represented 11.7 percent of the students, and the 1506 non-business education students represent 88.3 percent of the students included in this study.

\section{GPA FINDINGS}

The following data also separates the business education students from the non-business education students and reflects:

1. The number of students in each graduating class as well as the total number of students included in each group.

2. The GPA range for each graduating class and the total range for each group.

3. The mean GPA for each graduating class and the total mean for each group.

4. The percent of students that the data represents.

The number of students and their graduating classes shown in the GPA findings are the same group of students shown in the DAT find ings.

The GPA range for the business education students was from 1.15 to 3.95 as compared to from 1.00 to 3.95 for the non-business education students.

Business education students have a mean GPA of 2.56 compared to 2.68 for the non-business education students; the difference of .12 
was tested (Appendix D) and had a critical ratio of .86 , which is not significant.

TABLE \|\|

GPA RANGE AND MEAN FOR THE 1969 AND 1970

BUSINESS EDUCATION GRADUATES FROM

BEAVERTON AND SUNSET

HIGH SCHOOLS

\begin{tabular}{|c|c|c|c|c|c|}
\hline $\begin{array}{c}\text { Graduating } \\
\text { Class }\end{array}$ & $\begin{array}{l}\text { No. of } \\
\text { Students }\end{array}$ & $\begin{array}{l}\text { GPA R } \\
\text { From }\end{array}$ & $\begin{array}{r}\text { ange } \\
\text { To }\end{array}$ & Mean GPA & $\begin{array}{l}\text { Percent } \\
\text { of Class }\end{array}$ \\
\hline 1969 BHS & 63 & 1.35 & 3.75 & 2.56 & 13.3 \\
\hline 1969 SHS & 66 & 1.15 & 3.95 & 2.44 & 15.7 \\
\hline 1970 BHS & 27 & 1.55 & 3.65 & 2.86 & 6.7 \\
\hline 1970 SHS & 43 & 1.55 & 3.55 & 2.56 & 10.6 \\
\hline Total & 199 & 1.15 & 3.95 & 2.56 & 11.7 \\
\hline
\end{tabular}

One thing this study revealed that was not part of the original purpose was the sharp decline in the number of students enrolled in business education from 1969 to 1970. In 1969 there were 129 business education students and 764 non-business education students. In 1970 there were 70 business education students and 742 non-bus iness education students. The 129 business education students in 1969 represent 14.5 percent of the graduating class, while the 70 business education students in 1970 represent 8.65 percent of the graduating class. This 
shows a decline of 5.85 percent of business education students in 1970 as compared to 1969 .

TABLE IV

GPA RANGE AND MEAN FOR THE 1969 AND 1970

NON-BUSINESS EDUCATION GRADUATES

FROM BEAVERTON AND SUNSET

HIGH SCHOOLS

\begin{tabular}{|c|c|c|c|c|c|}
\hline $\begin{array}{c}\text { Graduating } \\
\text { Class }\end{array}$ & $\begin{array}{l}\text { No. of } \\
\text { Students }\end{array}$ & $\begin{array}{l}\text { GPA R } \\
\text { From }\end{array}$ & $\begin{array}{r}\text { ange } \\
\text { To }\end{array}$ & Mean GPA & $\begin{array}{l}\text { Percent } \\
\text { of Class }\end{array}$ \\
\hline 1969 BHS & 410 & 1.15 & 3.95 & 2.65 & 86.7 \\
\hline 1969 SHS & 354 & 1.25 & 3.95 & 2.56 & 84.3 \\
\hline 1970 BHS & 376 & 1.00 & 3.95 & 2.74 & 93.3 \\
\hline 1970 SHS & 366 & 1.00 & 3.95 & 2.68 & 89.4 \\
\hline Total & 1506 & 1.00 & 3.95 & 2.68 & 88.3 \\
\hline
\end{tabular}

111. SUMMARY

There was a total of 1705 students included in the study. There were 199 classified as business education students, and 1506 classified as non-business education students. The mean DAT score and GPA of the business education student was compared to the mean DAT score and GPA of the non-business education student.

The mean DAT score for the business education students was 56.35 as compared to 62.60 for the non-business education student. This difference was tested and found to be significant. 
The mean GPA for the business education students was 2.56 compared to 2.68 for the non-business education student. This difference was tested and found to be not significant.

This study also revealed a sharp decline in the number of students enrolled in business education in 1970 as compared to 1969.

The conclusions and recommendations of this comparative study are presented in the following chapter. 


\section{CHAPTER $V$}

\section{CONCLUSIONS AND RECOMMENDATIONS}

\section{INTRODUCTION}

Since some educators feel that it is the underachiever and the low-ability students who are placed in business education classes, the problem was to compare the potential ability and achievenent levels of business education students to that of students in other academic areas. To accomplish this, 1705 students from the graduating classes of 1969 and 1970 from Beaverton and Sunset High Schools were included in this study and classified as either business education students or non-business education students.

One of the first things this study revealed was that the number of students enrolled in business education classes declined in 1970 as compared to 1969.

A comparison was made of the mean DAT and GPA scores of the subjects included in this study. The differences were analyzed to determine significance. Business education students had a mean DAT score of 56.35 as compared to 62.60 for the non-business education students, a difference which was significant. Business education students had a GPA of 2.56 as compared to 2.68 for the non-bus iness education students, a difference which was not significant. 
Third, since this study revealed that the GPA of business education students nearly equals that of students enrolled in other academic courses, the possible reasons are:

1. Business education classes are more interesting than some other subjects.

2. The content of business education classes is such that less student performance is required.

3. Teachers' standards for student performance are lower than that required by other teachers.

4. Business education attracts the overachiever.

\section{RECOMMENDATIONS}

Since one of the main purposes of this study was to help in the guidance and placement of students in business education, the results have been given to the counseling departments at the involved schools. It is hoped that the results and the awareness of the condition that does exist will enable counselors to make a realistic assessment so these students can be placed in the proper channels.

A second purpose of this study was to provide helpful information upon which to base future curriculum planning. The business education departments at the involved schools have the results, and it is hoped they will consider them in developing future programs.

A third purpose of this study was to either verify or disprove the assumption that business education students are of a lower caliber. Since the assumptions are true, it is hoped that educators in general will consider this when working with future bus iness education students. 
Further studies are needed to:

1. Determine whether or not the decline of students enrolling in business education will continue.

2. Ascertain if the low-ability students are being channeled into new courses added to the school curriculum.

3. Reveal how business education students are performing in specific academic areas.

Such studies might be of additional value to counselors through a more effective channeling of students into appropriate interest areas and careers. 
FOOTNOTES

1"Business Education and the Slow Learner, An Awakening Giant," Balance Sheet, 47: 104-108 N.

2"slow Learners in Business Education," Balance Sheet, 49: 200-201 Ja.

3"Business and the Student Who is Not Academically Talented," Business Education Forum, 19: 7-8 $\mathrm{Mr}$.

4'Bus iness Education and the Slow Learner," Journal of Business Education, 43: $67-70 \mathrm{~N}$.

5uBusiness Education and the Superior Student, "Business Education Forum, 16: 1-9 Ja.

6"symposium--Business Education for Students of Lower Ability," Business Education Forum, 14: 30-34 Ja.

7 lbid., p. 31.

8 lbid., p. 31.

9lbid., p. 32.

10 Ibid., p. 33.

11 lbid., p. 34 . 


\section{BIBLIOGRAFHY}

Andrews, Margaret $E$. "Business Education Helps the Disadvantaged Student," Business Teacher, 45: 8-9 Ja-F.

Archer, Fred C. "Adapting Office Practice for Slow Learners," Business Teacher, 44: 12-13 JamF.

Byers, Edward E. "The Academically Unsuccessful," Business Teacher, 46: $23-28$ s-0.

Crawf is, Janice E. "The Slow Learner in Business Education," Journal of Business Education, 41: 19-21 $0 ; 65-67 \mathrm{~N}$.

Eyster, Elvia S. "Preparing the Lower One-Third in General Scholastic Ability for Business Employment," Journal of Business Education, 39: $180-81 \mathrm{~F}$.

Gray, V. Q. "Curriculum for Older Low-Achieving Impaired Students," Volta R., 68: $634-38 \mathrm{~N} 166$.

Haberman and Raths. "High, Average, Low: and What Makes Teachers Think So," Elementary School Journal, 68: 241-45 F.

Hamitt, H. "Evaluating and Reteaching Slow Learners," Arithmetic Teacher, $14: 40-41$ Ja 167.

Hemmel 1, James. "Business Challenges the Academically Talented," Balance Sheet, 41 : 340-42 Ap.

Henderson, Baxton. "Bookkeeping and the Low-Ability Student," Balance Sheet, 44: 251-52 F.

Herber, Joseph S. "Slow Learners in Business Education," Balance Sheet, 49: 200-201 Ja.

Humphrey, Frederick J. "The Low-Ability Student in Bookkeepingm-one School's Solution," Business Education Forum, 22: 16-170.

Jackson, E. G. "The Slow Learner," H. Points, 48: 58-59, Mr 166.

Krawitz, Myron J. "What Happens to the Reluctant Learners," Business Education World, 41: 18-20 Ja. 
MCFadden, D. L. "Stepping Stone for the Stranded," Journal of Industrial Arts Education, 28: $7 \mathrm{Mr} 169$.

Meyer, Dale G. "Business and the Student Who is not Academically Talented," Business Education Forum, 19: 7-8 Mr.

Olson, Milton C. "Business Education and the Superior Student," Business Education Forum, 16: 1-9 Ja.

Perry, Enos. "Symposium---Business Education for Students of Lower Ability," Business Education Forum, 14: 30-34 Ja.

Quinn, Rhonda L.. "Curriculum Offerings for Slow Learners in Business Education Departments of Public Schools in Madison County, lllinois," M. S. Thesis, Business Education Quarterly, 37: 380.

Rotrichild, Thomas A. "Business Education and the Slow Learner, An Awakening Giant," Balange Sheet, 47: 104-108.

Schultheis, Robert $A$. "A Descriptive Model of the Slow Learner," Delta Pi Epsilon, J 10: 19-26 Ag.

. "Business Education and the Slow Learner," Journal of Business Education, 43: 67-70 N.

- "The Potential Employability of Slow Learners in Record.. keeping Positions," Delta Pi Epsilon, J 10: 27-31 Ag.

Whitney, Eugene P. "A Program for Students with Special Needs," Journal of Business Education, 43: 6-7 0 . 
APPENDIX A

\begin{abstract}
DIFFERENTIAL APTITUDE TEST DEFINITION OF VERBAL REASONING AND NUMERICAL ABILITY
\end{abstract}

\title{
1. Verbal Reasoning
}

The Verbal Reasoning test, as its name implies, is a measure of ability to understand concepts framed in words. It is aimed at the evaluation of the student's ability to abstract or generalize and to think constructively, rather than at simple fluency or vocabulary recognition. The analogies form of test item is peculiarly appropriate for the measurement of reasoning ability. The particular type of analogies item devised for this test is especially useful because it provides: 1 , a highly reliable item; 2 , a very versatile item; and 3 , a measure of reasoning that is relatively complex without being tricky or esoteric.

The item type is unusually reliable in that the chances are only one in sixteen that any correct answer will be guessed; in most multiple-choice test items, the chances are one in four or five. This high reliability of each individual item makes unnecessary the use of a scoring formula which corrects for guessing.

The item type is versatile. Its structure requires real thinking to supply the correct response to each item. At the same time, the content of the items may be varied as much as desired. The words used in these items may come from history, geography, literature, science, or any other content area. The item thus samples the student's knowledge and his ability to abstract and generalize relationships inherent in that knowledge.

The simple analogy has been widely used since its inclusion in the earliest group tests of intelligence. The very extent of its use is testimony to its applicability as a measure of general intelligence. All too often, however, the simple analogy is solved on the bas is of association rather than real thinking; furthermore, difficult items are typically obtained by employing rare items of knowledge from subject matter fields, or very unusual vocabulary terms. For the present test, the item type used overcomes both these drawbacks; the vocabulary is for the most part relatively simple, and trie content is reasonably familiar. The additional 
complexity, and additional item difficulty where desired, are functions of the reasoning process required (95).

The Verbal Reasoning test may be expected to predict with reasonable accuracy success in fields where complex verbal relationships and concepts are important.

In judgments as to whether or not a student is likely "college material," the Vertal Reasoning test score deserves considerable weight. Vocationally, the test also indicates something of the occupational level to which the student may appropriately aspire, since there is a positive relationship in many occupations between the level of responsibility of a job and the complexity of verbally phrased ideas to be comprehended.

\section{Numerical Ability}

The Numerical Ability items are designed to test understanding of numerical relationships and facility in handling numerical concepts. The problems are framed in the item type usually called "arithmetic computation" rather than in what is usually called "arithmetic reasoning." This was prompted by the desire to avoid the language elements of the usual arithmetic reasoning problem, in which reading ability may play a significant role. The computation form has the advantage of not being thus contaminated as a measure of numerical ability.

It is evident from inspection of the items that the measurement of reasoning ability is not sacrificed by the use of the computation type. Some of the items test only for skill in numerical processes; this is necessary information for guidance purposes. Many of the items, however, call for understanding of numerical relationships; though computationally simple, they are, as problems, fully as complex as items usually framed in verbal terms. It was demonstrated by actual tryout in the schools that they are sufficiently complex to challenge students in all high school grades.

The test has been so devised as to require intelligent handling of the concepts, and answers are scored with this principle in mind. For example, in a problem of the test, the answer $47 \mathrm{ft}$., $24 \mathrm{in}$. is scored as wrong, even though it is the correct sum arithmetically; only $49 \mathrm{ft}$. is accepted. The student who has given the former response has not responded intelligently; he has failed to perceive the relationship in the feet and inches combination. An employer or teacher would look askance at someone who, when asked to measure a table, replied 114 feet, 12 inches." The same approach to evaluation of numerical understanding is applied in this test. 
The Numerical Ability test is a measure of the student's ability to reason with numbers, to manipulate numerical relationships and to deal intelligently with quantitative materials. It teams with the Verbal Reasoning test as a measure of general learning ability. Educationally it is important for prediction in such fields as mathematics, physics, chemistry, engineering, and other curricula in which quantitative thinking is essential. Various amounts of numerical ability are required in occupations such as laboratory assistant, bookkeeper, statistician, and shipping clerk; in carpentry, tool making, and other crafts as well as in professions related to the physical sciences. 
APPENDIX B

SURVEY INSTRUMENT

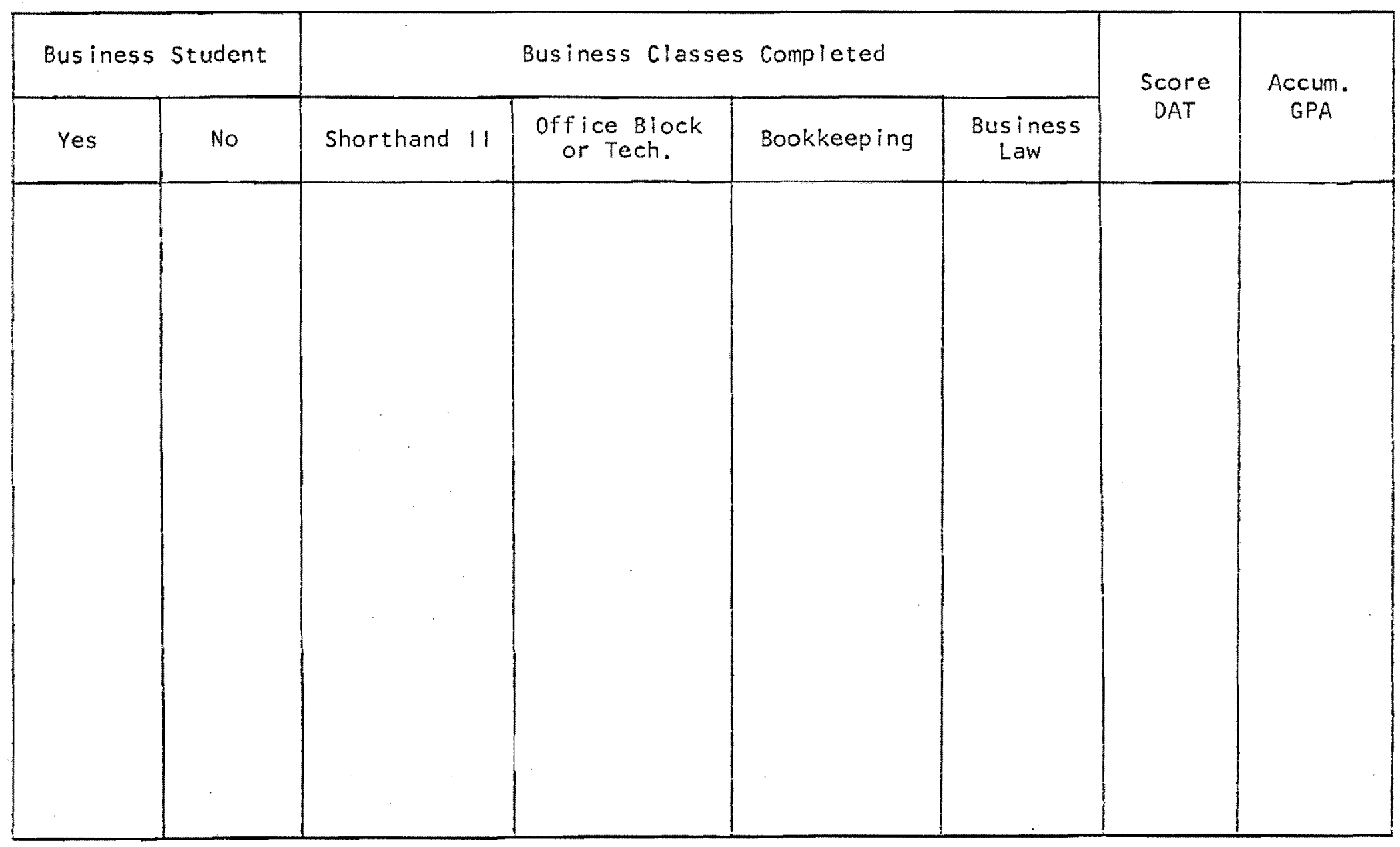


APPEND IX C

FREQUENCY DISTRIBUTION OF DAT SCORES

FOR 1969 BEAVERTON HIGH SCHOOL.

BUSINESS EDUCATION GRADUATES

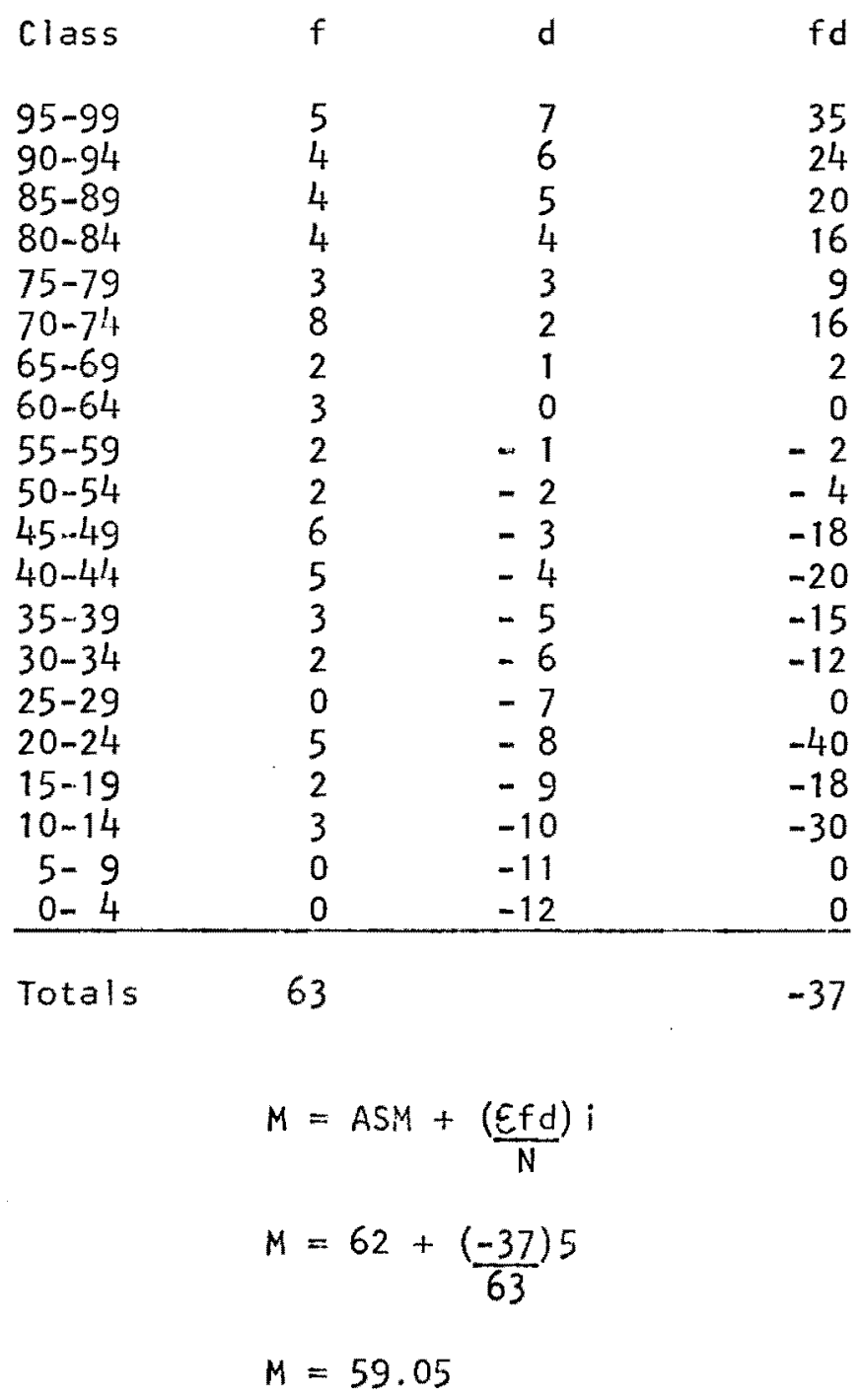




\section{FREQUENCY DISTRIBUTION OF DAT SCORES FOR 1969 SUNSET HIGH SCHOOL \\ BUSINESS EDUCATION GRADUATES}

\begin{tabular}{rrrr} 
Class & $f$ & $d$ & $f d$ \\
$95-99$ & 4 & 10 & 40 \\
$90-94$ & 3 & 9 & 27 \\
$85-89$ & 3 & 8 & 24 \\
$80-84$ & 4 & 7 & 28 \\
$75-79$ & 4 & 6 & 24 \\
$70-74$ & 3 & 5 & 15 \\
$65-69$ & 5 & 4 & 20 \\
$60-64$ & 3 & 3 & 9 \\
$55-59$ & 1 & 2 & 2 \\
$50-54$ & 3 & 1 & 3 \\
$45-49$ & 3 & 0 & 0 \\
$40-44$ & 4 & -1 & -10 \\
$35-39$ & 5 & -2 & -15 \\
$30-34$ & 5 & -3 & -8 \\
$25-29$ & 2 & -4 & -20 \\
$20-24$ & 4 & -5 & -30 \\
$15-19$ & 5 & -6 & -28 \\
$10-14$ & 4 & -7 & 0 \\
$5-9$ & 0 & -8 & -9 \\
$0-4$ & 1 & -9 & 68 \\
\hline Totals & 66 & &
\end{tabular}

$$
\begin{aligned}
& M=A S M+\frac{(E f d)}{N} i \\
& M=47+\frac{(68)}{66} 5 \\
& M=52.15
\end{aligned}
$$


FREQUENCY DISTRIBUTION OF DAT SCORES

FOR 1970 BEAVERTON HIGH SCHOOL

BUSINESS EDUCATION GRADUATES

\begin{tabular}{rrrr} 
Class & $f$ & $d$ & $f d$ \\
$95-99$ & 4 & 7 & 28 \\
$90-94$ & 1 & 6 & 6 \\
$85-89$ & 2 & 5 & 10 \\
$80-84$ & 1 & 4 & 4 \\
$74-79$ & 2 & 3 & 6 \\
$70-74$ & 2 & 2 & 4 \\
$65-69$ & 1 & 1 & 1 \\
$60-64$ & 3 & 0 & 0 \\
$55-59$ & 3 & -1 & -3 \\
$50-54$ & 1 & -2 & -2 \\
$45-49$ & 0 & -3 & 0 \\
$40-44$ & 1 & -4 & -4 \\
$35-39$ & 1 & -5 & -6 \\
$30-34$ & 1 & -6 & -7 \\
$25-29$ & 1 & -7 & -8 \\
$20-24$ & 1 & -8 & -9 \\
$15-19$ & 1 & -9 & -10 \\
$10-14$ & 1 & -10 & 0 \\
$5-9$ & 0 & -11 & 0 \\
$0-4$ & 0 & -12 & 5 \\
\hline
\end{tabular}

$$
\begin{aligned}
& M=A S M+\frac{\left(\varepsilon_{f d}\right)}{N} i \\
& M=62+\frac{(5) 5}{27} 5 \\
& M=62.95
\end{aligned}
$$


FREQUENCY DISTRIBUTION OF DAT SCORES FOR 1970 SUNSET HIGH SCHOOL BUSINESS EDUCATION GRADUATES

\begin{tabular}{rrrr} 
Class & $f$ & $d$ & $f d$ \\
$95-99$ & 2 & 8 & 16 \\
$90-94$ & 2 & 7 & 14 \\
$85-89$ & 3 & 6 & 18 \\
$80-84$ & 2 & 5 & 10 \\
$75-79$ & 2 & 4 & 8 \\
$70-74$ & 4 & 3 & 12 \\
$65-69$ & 3 & 2 & 6 \\
$60-64$ & 0 & 1 & 0 \\
$55-59$ & 5 & 0 & 0 \\
$50-54$ & 3 & -1 & -3 \\
$45-49$ & 2 & -2 & -4 \\
$40-44$ & 3 & -3 & -4 \\
$35-39$ & 1 & -4 & 0 \\
$30-34$ & 0 & -5 & -24 \\
$25-29$ & 4 & -6 & -14 \\
$20-24$ & 2 & -7 & -8 \\
$15-19$ & 1 & -8 & -18 \\
$10-14$ & 2 & -9 & -20 \\
$5-9$ & 2 & -10 & 0 \\
$0-4$ & 0 & -11 & -20 \\
\hline Totals & 43 & &
\end{tabular}

$$
\begin{aligned}
& M=A S M+\frac{(E f d)}{N} i \\
& M=57+\frac{(-20)}{43} 5 \\
& M=54.65
\end{aligned}
$$




\section{FREQUENCY DISTRIBUTION OF DAT SCORES \\ FOR 1969 BEAVERTON HIGH SCHOOL. \\ NON-BUSINESS EDUCATION GRADUATES}

\begin{tabular}{rrrr} 
Class & $f$ & $d$ & $f d$ \\
& & & $f$ \\
$95-99$ & 58 & 6 & 348 \\
$90-94$ & 25 & 5 & 125 \\
$85-89$ & 18 & 4 & 72 \\
$80-84$ & 37 & 3 & 111 \\
$75-79$ & 29 & 2 & 58 \\
$70-74$ & 37 & 1 & 37 \\
$65-69$ & 27 & 0 & 0 \\
$60-64$ & 19 & -1 & -34 \\
$55-59$ & 17 & -2 & -45 \\
$50-54$ & 15 & -3 & -60 \\
$45-49$ & 15 & -4 & -95 \\
$40-44$ & 19 & -5 & -132 \\
$35-39$ & 22 & -6 & -119 \\
$30-34$ & 17 & -7 & -56 \\
$25-29$ & 7 & -8 & -135 \\
$20-24$ & 15 & -9 & -170 \\
$15-19$ & 17 & -10 & -77 \\
$10-14$ & 7 & -11 & -60 \\
$5-9$ & 5 & -12 & -52 \\
$0-4$ & 4 & -13 & -303 \\
\hline Totals & 410 & &
\end{tabular}

$$
\begin{aligned}
& M=A S M+\frac{(E f d)}{N} i \\
& M=67+\frac{(-303)}{410} 5 \\
& M=63.30
\end{aligned}
$$


FREQUENCY DISTRIBUTION OF DAT SCORES

FOR 1969 SUNSET HIGH SCHOOL NON-BUSINESS EDUCATION GRADUATES

\begin{tabular}{rrrr} 
Class & $f$ & $d$ & $f d$ \\
$95-99$ & 41 & 7 & 287 \\
$90-94$ & 26 & 6 & 156 \\
$85-89$ & 11 & 5 & 55 \\
$80-84$ & 20 & 4 & 80 \\
$75-79$ & 23 & 3 & 69 \\
$70-74$ & 33 & 2 & 66 \\
$65-69$ & 20 & 1 & 20 \\
$60-64$ & 11 & 0 & 0 \\
$55-59$ & 24 & -1 & -24 \\
$50-54$ & 15 & -2 & -30 \\
$45-49$ & 15 & -3 & -45 \\
$40-44$ & 21 & -4 & -84 \\
$35-39$ & 22 & -5 & -110 \\
$30-34$ & 23 & -6 & -738 \\
$25-29$ & 10 & -7 & -88 \\
$20-24$ & 11 & -8 & -108 \\
$15-19$ & 12 & -9 & -50 \\
$10-14$ & 5 & -10 & -66 \\
$5-9$ & 6 & -11 & -60 \\
$0-4$ & 5 & -12 & -140 \\
\hline Totals & 354 & &
\end{tabular}

$$
\begin{aligned}
& M=A S M+\frac{(\varepsilon f d)}{N} i \\
& M=62+\frac{(-140)}{354} 5 \\
& M=60.00
\end{aligned}
$$




\section{FREQUENCY DISTRIBUTION OF DAT SCORES \\ FOR 1970 BEAVERTON HIGH SCHOOL \\ NON-BUSINESS EDUCATION GRADUATES}

\begin{tabular}{rrrr} 
Class & $f$ & $d$ & $f d$ \\
$95-99$ & 54 & 6 & 324 \\
$90-94$ & 36 & 5 & 180 \\
$85-89$ & 24 & 4 & 96 \\
$80-84$ & 25 & 3 & 75 \\
$75-79$ & 27 & 2 & 54 \\
$70-74$ & 20 & 1 & 20 \\
$65-69$ & 17 & 0 & 0 \\
$60-64$ & 19 & -1 & -19 \\
$55-59$ & 24 & -2 & -48 \\
$50-54$ & 16 & -3 & -72 \\
$45-49$ & 18 & -4 & -70 \\
$40-44$ & 14 & -5 & -96 \\
$35-39$ & 16 & -6 & -77 \\
$30-34$ & 11 & -7 & -128 \\
$25-29$ & 16 & -8 & -99 \\
$20-24$ & 11 & -9 & -60 \\
$15-19$ & 6 & -10 & -110 \\
$10-14$ & 10 & -11 & -132 \\
$5-9$ & 11 & -12 & -13 \\
$0-4$ & 1 & -13 & -223 \\
\hline Totals & 376 & &
\end{tabular}

$$
\begin{aligned}
& M=A S M+\frac{(\varepsilon f d)}{N} i \\
& M=67+\frac{(-223)}{376} 5 \\
& M=64.05
\end{aligned}
$$


FREQUENCY DISTRIBUTION OF DAT SCORES

FOR 1970 SUNSET HIGH SCHOOL

NON-BUSINESS EDUCATION GRADUATES

\begin{tabular}{ccrr} 
Class & $f$ & $d$ & \multicolumn{1}{c}{$f d$} \\
$95-99$ & 45 & 6 & 270 \\
$90-94$ & 22 & 5 & 110 \\
$85-89$ & 22 & 4 & 88 \\
$80-814$ & 27 & 3 & 71 \\
$75-79$ & 25 & 2 & 50 \\
$70-74$ & 24 & 1 & 24 \\
$65-69$ & 33 & 0 & 0 \\
$60-64$ & 15 & -1 & -15 \\
$55-59$ & 25 & -2 & -50 \\
$50-54$ & 15 & -3 & -45 \\
$45-49$ & 11 & -4 & -44 \\
$40-44$ & 23 & -5 & -115 \\
$35-39$ & 24 & -6 & -144 \\
$30-34$ & 11 & -7 & -77 \\
$25-29$ & 11 & -8 & -88 \\
$20-24$ & 7 & -9 & -63 \\
$15-19$ & 8 & -10 & -80 \\
$10-14$ & 7 & -11 & -77 \\
$5-9$ & 8 & -12 & -96 \\
$0-4$ & 3 & -13 & -39 \\
\hline
\end{tabular}

$$
\begin{aligned}
& M=A S M+\frac{(E f d)}{N} i \\
& M=67+\frac{(-320) 5}{366} 5 \\
& M=62.65
\end{aligned}
$$


FREQUENCY DISTRIBUTION OF DAT SCORES FOR 1969 AND 1970 BEAVERTON AND SUNSET HIGH SCHOOL BUSINESS EDUCATION GRADUATES

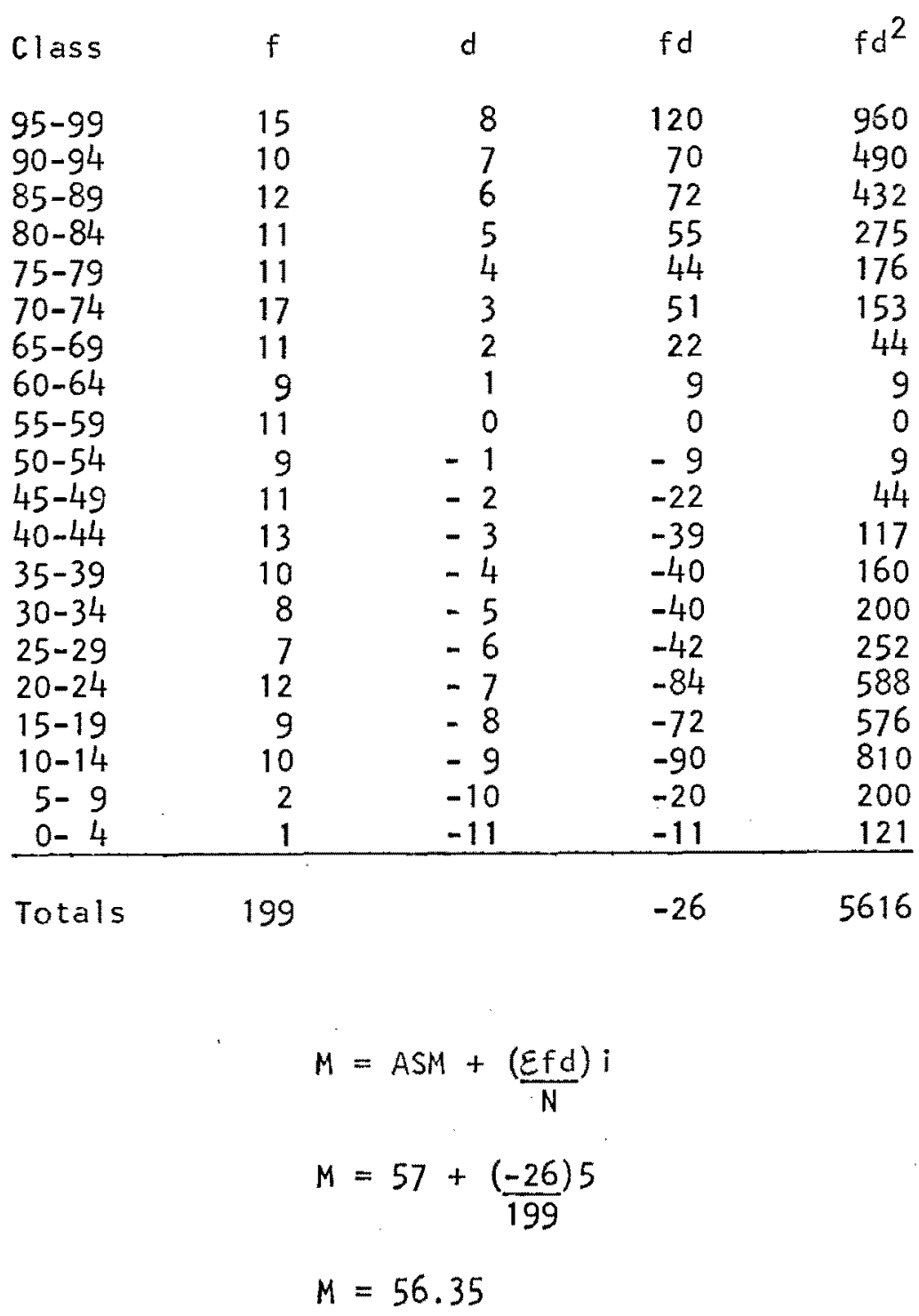


FREQUENCY DISTRIBUTION OF DAT SCORES FOR 1969 AND 1970 BEAVERTON AND SUNSET HIGH SCHOOL NON-BUSINESS EDUCATION GRADUATES

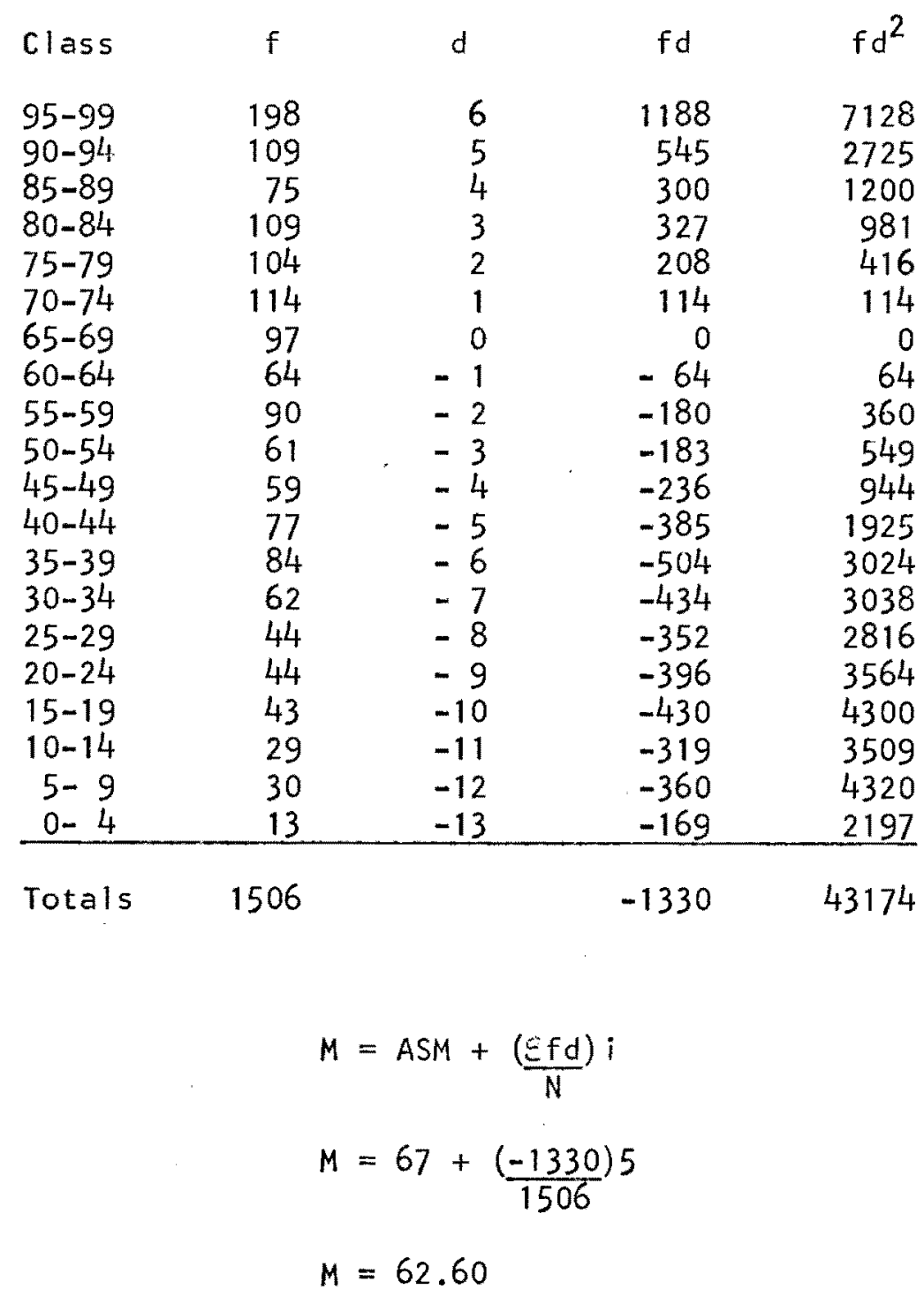


FREQUENCY DISTRIBUTION OF GPAS FOR 1969 BEAVERTON HIGH SCHOOL BUSINESS EDUCATION GRADUATES

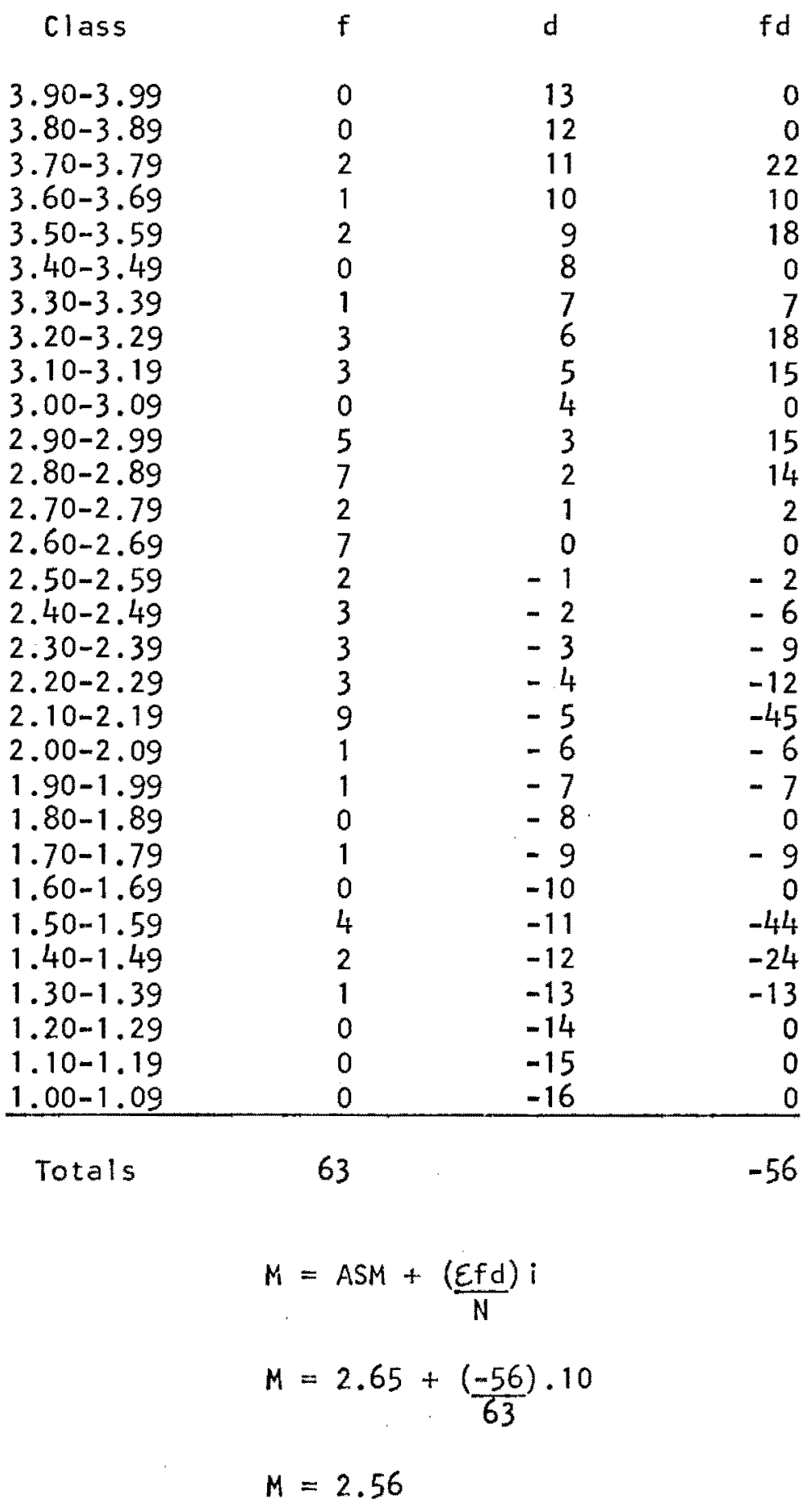


FREQUENCY DISTRIBUTION OF GPAS FOR 1969 SUNSET HIGH SCHOOL BUSINESS EDIJCATION GRADUATES

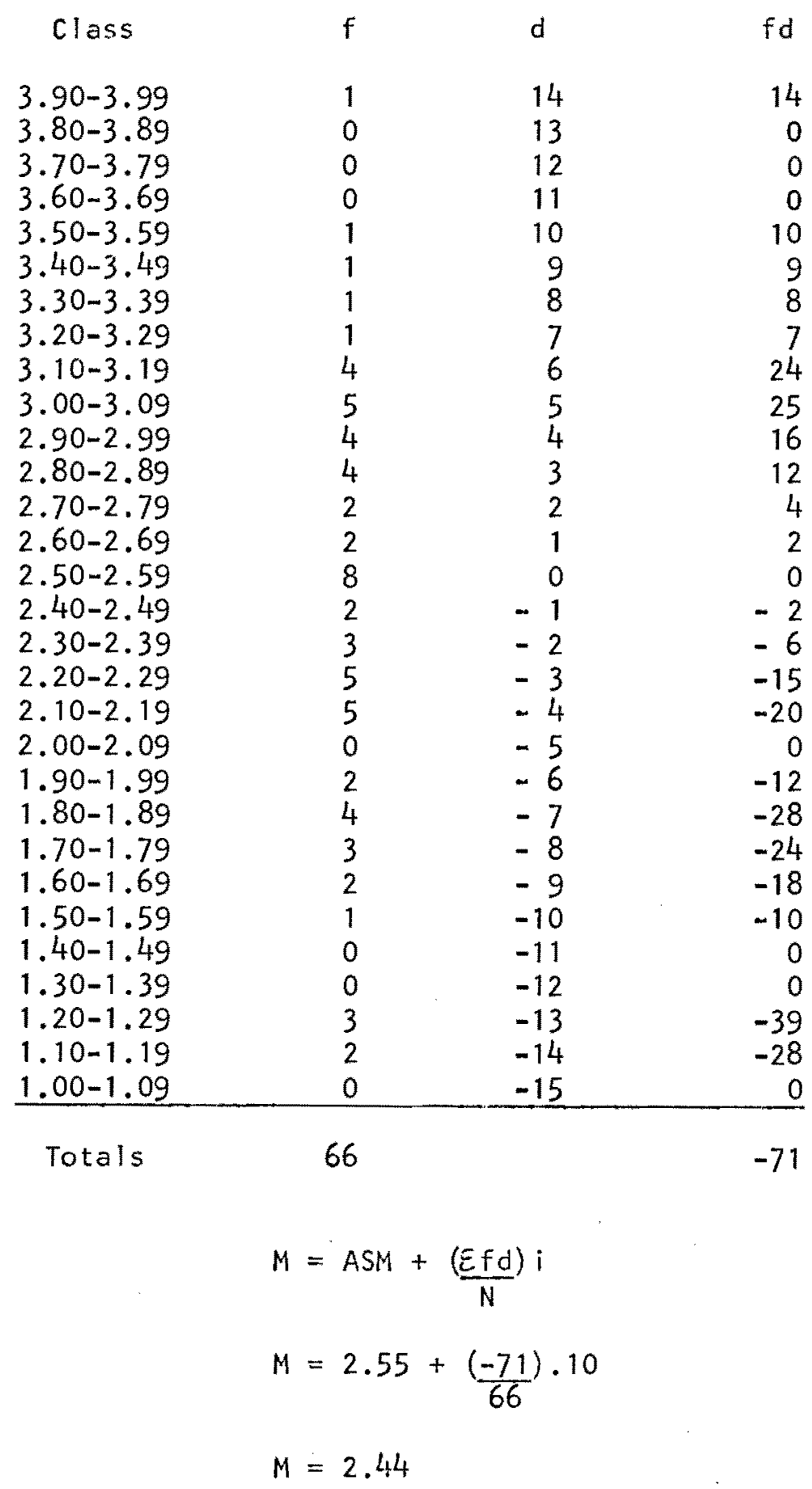


FREQUENCY DISTRIBUTION OF GPAS FOR 1970 BEAVERTON HIGH SCHOOL BUSINESS EDUCATION GRADUATES

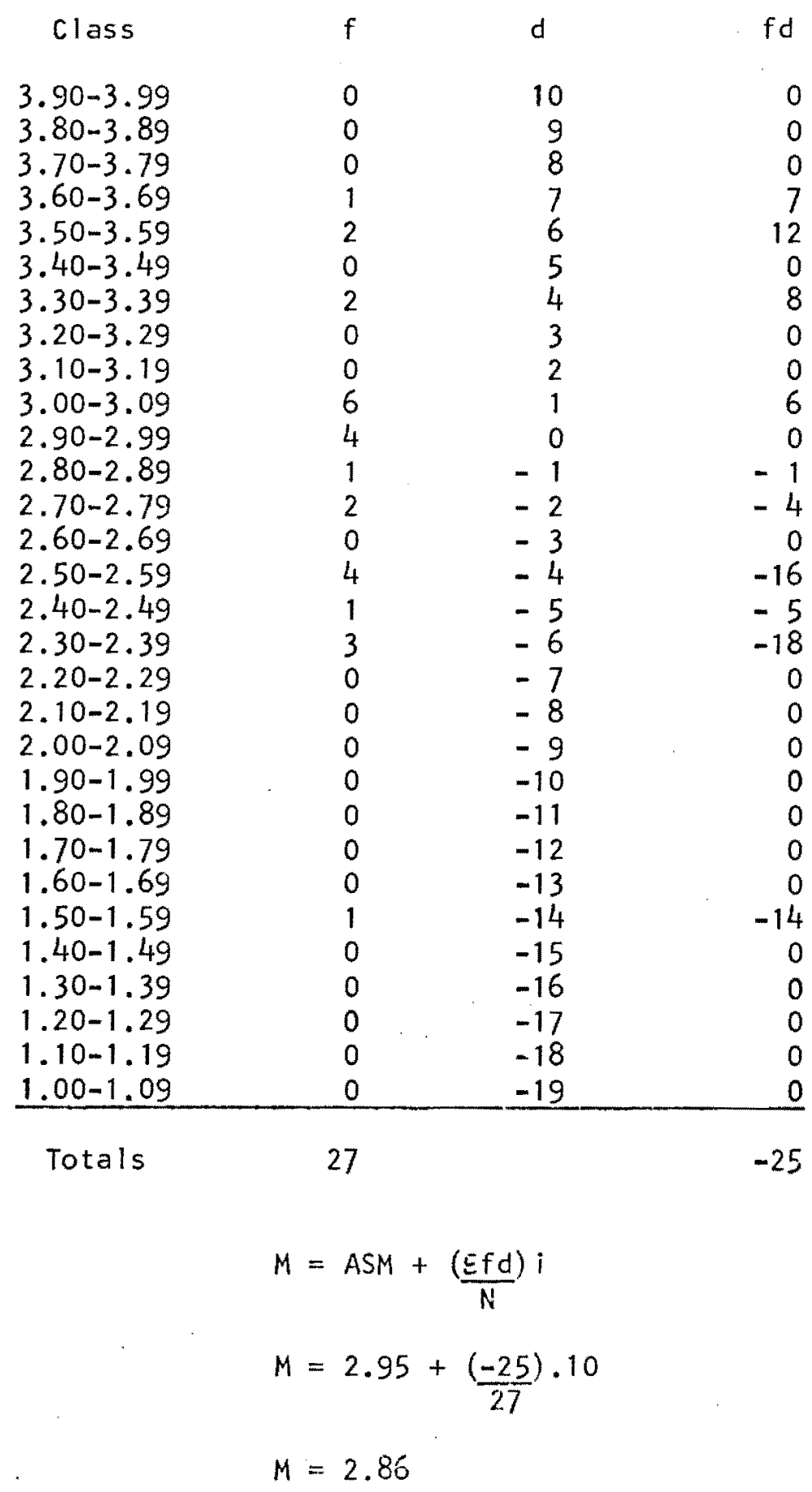




\section{FREQUENCY DISTRIBUTION OF GPAS FOR 1970 SUNSET HIGH SCHOOL \\ BUSINESS EDUCATION GRADUATES}

\begin{tabular}{|c|c|c|c|}
\hline Class & $f$ & $d$ & $f d$ \\
\hline $3.90-3.99$ & 0 & 14 & 0 \\
\hline $3.80-3.89$ & 0 & 13 & 0 \\
\hline $3.70-3.79$ & 0 & 12 & 0 \\
\hline $3.60-3.69$ & 0 & 11 & 0 \\
\hline $3.50-3.59$ & 2 & 10 & 20 \\
\hline $3.40-3.49$ & 0 & 9 & 0 \\
\hline $3.30-3.39$ & 1 & 8 & 8 \\
\hline $3.20-3.29$ & 2 & 7 & 14 \\
\hline $3.10-3.19$ & 1 & 6 & 6 \\
\hline $3.00-3.09$ & 4 & 5 & 20 \\
\hline $2.90-2.99$ & 0 & 4 & 0 \\
\hline $2.80-2.89$ & 2 & 3 & 6 \\
\hline $2.70-2.79$ & 3 & 2 & 0 \\
\hline $2.60-2.69$ & 4 & 1 & 4 \\
\hline $2.50-2.59$ & 5 & 0 & 0 \\
\hline $2.40-2.49$ & 5 & -1 & -5 \\
\hline $2.30-2.39$ & 3 & -2 & -6 \\
\hline $2.20-2.29$ & 2 & -3 & - \\
\hline $2.10-2.19$ & 2 & -4 & -8 \\
\hline $2.00-2.09$ & 2 & -5 & -10 \\
\hline $1.90-1.99$ & 1 & -6 & -6 \\
\hline $1.80-1.89$ & 0 & -7 & 0 \\
\hline $1.70-1.79$ & 0 & -8 & 0 \\
\hline $1.60-1.69$ & 2 & -9 & -18 \\
\hline $1.50-1.59$ & 2 & -10 & -20 \\
\hline $1.40-1.49$ & 0 & -11 & \\
\hline $1.30-1.39$ & 0 & -12 & \\
\hline $1.20-1.29$ & 0 & -13 & 0 \\
\hline $1.10-1.19$ & 0 & -14 & 0 \\
\hline $1.00-1.09$ & 0 & -15 & 0 \\
\hline
\end{tabular}

$$
\begin{aligned}
& M=A S M+\frac{(E f d)}{N} i \\
& M=2.55+\frac{(5)}{43} \cdot 10 \\
& M=2.56
\end{aligned}
$$


FREQUENCY DISTRIBUTION OF GPAS

FOR 1969 BEAVERTON HIGH SCHOOL NON-BUSINESS EDUCATION GRADUATES

\begin{tabular}{|c|c|c|c|}
\hline Class & $f$ & $d$ & $f d$ \\
\hline $3.90-3.99$ & 3 & 13 & 39 \\
\hline $3.80-3.89$ & 9 & 12 & 108 \\
\hline $3.70-3.79$ & 2 & 11 & 22 \\
\hline $3.60-3.69$ & 7 & 10 & 70 \\
\hline $3.50-3.59$ & 18 & 9 & 162 \\
\hline $3.40-3.49$ & 24 & 8 & 192 \\
\hline $3.30-3.39$ & 17 & 7 & 119 \\
\hline $3.20-3.29$ & 18 & 6 & 108 \\
\hline $3.10-3.19$ & 13 & 5 & 65 \\
\hline $3.00-3.09$ & 19 & 4 & $\gamma$ \\
\hline $2.90-2.99$ & 22 & 3 & 6 \\
\hline $2.80-2.89$ & 25 & 2 & 5 \\
\hline $2.70-2.79$ & 20 & 1 & 2 \\
\hline $2.60-2.69$ & 19 & 0 & \\
\hline $2.50-2.59$ & 19 & -1 & -19 \\
\hline $2.40-2.49$ & 23 & -2 & -46 \\
\hline $2.30-2.39$ & 26 & -3 & -78 \\
\hline $2.20-2.29$ & 19 & -4 & -76 \\
\hline $2.10-2.19$ & 18 & -5 & -90 \\
\hline $2.00-2.09$ & 23 & -6 & -138 \\
\hline $1.90-1.99$ & 17 & -7 & -11 \\
\hline $1.80-1.89$ & 14 & -8 & -112 \\
\hline $1.70-1.79$ & 7 & -9 & -63 \\
\hline $1.60-1.69$ & 4 & -10 & -4 \\
\hline $1.50-1.59$ & 4 & -11 & -4 \\
\hline $1.40-1.49$ & 8 & -12 & -9 \\
\hline $1.30-1.39$ & 3 & -13 & -3 \\
\hline $1.20-1.29$ & 4 & -14 & -5 \\
\hline $1.10-1.19$ & 5 & -15 & -75 \\
\hline $1.00-1.09$ & 0 & -16 & \\
\hline
\end{tabular}

$$
\begin{aligned}
& M=A S M+\frac{(E f d)}{N} i \\
& M=2.65+\frac{(6)}{410} \cdot 10 \\
& M=2.65
\end{aligned}
$$




\section{FREQUENCY DISTRIBUTION OF GPAS \\ FOR 1969 SUNSET HIGH SCHOOL NON-BUSINESS EDUCATION GRADUATES}

\begin{tabular}{|c|c|c|c|}
\hline Class & $f$ & d & $f d$ \\
\hline $3.90-3.99$ & 4 & 14 & 56 \\
\hline $3.80-3.89$ & 2 & 13 & 26 \\
\hline $3.70-3.79$ & 8 & 12 & 96 \\
\hline $3.60-3.69$ & 5 & 11 & 55 \\
\hline $3.50-3.59$ & 9 & 10 & 90 \\
\hline $3.40-3.49$ & 7 & 9 & 63 \\
\hline $3.30-3.39$ & 16 & 8 & 128 \\
\hline $3.20-3.29$ & 15 & 7 & 105 \\
\hline $3.10-3.19$ & 15 & 6 & 90 \\
\hline $3.00-3.09$ & 16 & 5 & 80 \\
\hline $2.90-2.99$ & 14 & 4 & 56 \\
\hline $2.80-2.89$ & 22 & 3 & 66 \\
\hline $2.70-2.79$ & 19 & 2 & 38 \\
\hline $2.60-2.69$ & 20 & 1 & 20 \\
\hline $2.50-2.59$ & 23 & 0 & 0 \\
\hline $2.40-2.49$ & 15 & -1 & -15 \\
\hline $2.30-2.39$ & 14 & -2 & -28 \\
\hline $2.20-2.29$ & 15 & -3 & -45 \\
\hline $2.10-2.19$ & 12 & -4 & -48 \\
\hline $2.00-2.09$ & 20 & -5 & -100 \\
\hline $1.90-1.99$ & 20 & -6 & -120 \\
\hline $1.80-1.89$ & 11 & -7 & -77 \\
\hline $1.70-1.79$ & 13 & -8 & -104 \\
\hline $1.60-1.69$ & 8 & -9 & -72 \\
\hline $1.50-1.59$ & 12 & -10 & -120 \\
\hline $1.40-1.49$ & 8 & -11 & -88 \\
\hline $1.30-1.39$ & 8 & -12 & -96 \\
\hline $1.20-1.29$ & 3 & -13 & -39 \\
\hline $1.10-1.19$ & 0 & -14 & 0 \\
\hline $1.00-1.09$ & 0 & -15 & 0 \\
\hline
\end{tabular}

$$
\begin{aligned}
& M=A S M+\frac{(\varepsilon f d)}{N} i \\
& M=2.55+\left(\frac{17}{354}\right) \cdot 10 \\
& M=2.56
\end{aligned}
$$


FREQUENCY DISTRIBUTION OF GPAS FOR 1970 BEAVERTON HIGH SCHOOL NON-BUSINESS EDUCATION GRADUATES

\begin{tabular}{|c|c|c|c|}
\hline Class & $f$ & $d$ & $f d$ \\
\hline $3.90-3.99$ & 2 & 11 & 22 \\
\hline $3.80-3.89$ & 10 & 10 & 100 \\
\hline $3.70-3.79$ & 5 & 9 & 45 \\
\hline $3.60-3.69$ & 11 & & 88 \\
\hline $3.50-3.59$ & 21 & 7 & 147 \\
\hline $3.40-3.49$ & 18 & 6 & 108 \\
\hline $3.30-3.39$ & 20 & 5 & 100 \\
\hline $3.20-3.29$ & 18 & 4 & 72 \\
\hline $3.10-3.19$ & 23 & 3 & 69 \\
\hline $3.00-3.09$ & 23 & 2 & 46 \\
\hline $2.90-2.99$ & 22 & 1 & 22 \\
\hline $2.80-2.89$ & 21 & 0 & \\
\hline $2.70-2.79$ & 21 & -1 & -21 \\
\hline $2.60-2.69$ & 20 & -2 & -40 \\
\hline $2.50-2.59$ & 19 & -3 & -57 \\
\hline $2.40-2.49$ & 9 & -4 & -36 \\
\hline $2.30-2.39$ & 16 & -5 & -80 \\
\hline $2.20-2.29$ & 15 & -6 & -90 \\
\hline $2.10-2.19$ & 10 & -7 & -70 \\
\hline $2.00-2.09$ & 12 & -8 & -96 \\
\hline $1.90-1.99$ & 10 & -9 & -90 \\
\hline $1.80-1.89$ & 6 & -10 & -60 \\
\hline $1.70-1.79$ & 5 & -11 & -55 \\
\hline $1.60-1.69$ & 8 & -12 & -96 \\
\hline $1.50-1.59$ & 11 & -13 & -143 \\
\hline $1.40-1.49$ & 7 & -14 & -98 \\
\hline $1.30-1.39$ & 6 & -15 & -90 \\
\hline $1.20-1.29$ & 4 & -16 & -64 \\
\hline $1.10-1.19$ & 2 & -17 & $\begin{array}{l}-34 \\
-38\end{array}$ \\
\hline $1.00-1.09$ & 1 & -18 & -18 \\
\hline Totals & 376 & & -419 \\
\hline \multicolumn{4}{|c|}{$M=A S M+\left(\frac{E f d}{N} i\right.$} \\
\hline & \multicolumn{3}{|c|}{$M=2.85+\frac{(-419)}{376} \cdot 10$} \\
\hline & $M=$ & & \\
\hline
\end{tabular}


FREQUENCY DISTRIBUTION OF GPAS

FOR 1970 SUNSET HIGH SCHOOL.

NON-BUSINESS EDUCATION GRADUATES

\begin{tabular}{|c|c|c|c|}
\hline Class & $f$ & d & $\mathrm{fd}$ \\
\hline $3.90-3.99$ & 2 & 12 & 24 \\
\hline $3.80-3.89$ & 4 & 11 & 44 \\
\hline $3.70-3.79$ & 8 & 10 & 80 \\
\hline $3.60-3.69$ & 8 & 9 & 72 \\
\hline $3.50-3.59$ & 12 & 8 & 96 \\
\hline $3.40-3.49$ & 13 & 7 & 91 \\
\hline $3.30-3.39$ & 17 & 6 & 102 \\
\hline $3.20-3.29$ & 19 & 5 & 95 \\
\hline $3.10-3.19$ & 18 & 4 & 72 \\
\hline $3.00-3.09$ & 24 & 3 & 72 \\
\hline $2.90-2.99$ & 20 & 2 & 40 \\
\hline $2.80-2.89$ & 22 & 1 & 22 \\
\hline $2.70-2.79$ & 22 & 0 & 0 \\
\hline $2.60-2.69$ & 23 & -1 & -23 \\
\hline $2.50-2.59$ & 18 & -2 & -36 \\
\hline $2.40-2.49$ & 16 & -3 & -48 \\
\hline $2.30-2.39$ & 16 & -5 & -64 \\
\hline $2.20-2.29$ & 18 & -5 & -90 \\
\hline $2.10-2.19$ & 15 & -6 & -90 \\
\hline $2.00-2.09$ & 19 & -7 & -133 \\
\hline $1.90-1.99$ & 13 & -8 & -104 \\
\hline $1.80-1.89$ & 5 & -9 & -45 \\
\hline $1.70-1.79$ & 6 & -10 & -60 \\
\hline $1.60-1.69$ & 7 & -11 & -77 \\
\hline $1.50-1.59$ & 7 & -12 & -84 \\
\hline $1.40-1.49$ & 4 & -13 & -52 \\
\hline $1.30-1.39$ & 5 & -14 & -70 \\
\hline $1.20-1.29$ & 2 & -15 & -30 \\
\hline $1.10-1.19$ & 0 & -16 & 0 \\
\hline $1.00-1.09$ & 3 & -17 & -51 \\
\hline Tata lo & 366 & & -247 \\
\hline
\end{tabular}

$M=A S M+\frac{(\underline{\varepsilon f d})}{N} i$

$M=2.75+\frac{(-247)}{366} \cdot 10$

$M=2.68$ 
FREQUENCY DISTRIBUTION OF GPAS FOR 1969 AND 1970 BEAVERTON AND SUNSET HIGH SCHOOL BUSINESS EDUCATION GRADUATES

\begin{tabular}{|c|c|c|c|c|}
\hline Class & $f$ & d & $f d$ & $f d^{2}$ \\
\hline $3.90-3.99$ & 1 & 14 & 14 & 196 \\
\hline $3.80-3.89$ & 0 & 13 & 0 & 0 \\
\hline $3.70-3.79$ & 2 & 12 & 24 & 288 \\
\hline $3.60-3.69$ & 2 & 11 & 22 & 242 \\
\hline $3.50-3.59$ & 7 & 10 & 70 & 700 \\
\hline $3.40-3.49$ & 1 & 9 & 9 & 81 \\
\hline $3.30-3.39$ & 5 & 8 & 40 & 320 \\
\hline $3.20-3.29$ & 6 & 7 & 42 & 294 \\
\hline $3.10-3.19$ & 8 & 6 & 48 & 288 \\
\hline $3.00-3.09$ & 15 & 5 & 75 & 375 \\
\hline $2.90-2.99$ & 13 & 4 & 52 & 208 \\
\hline $2.80-2.89$ & 14 & 3 & 42 & 126 \\
\hline $2.70-2.79$ & 9 & 2 & 18 & 36 \\
\hline $2.60-2.69$ & 13 & 1 & 13 & 13 \\
\hline $2.50-2.59$ & 19 & 0 & 0 & 0 \\
\hline $2.40-2.49$ & 11 & -1 & -11 & 11 \\
\hline $2.30-2.39$ & 12 & -2 & -24 & 48 \\
\hline $2.20-2.29$ & 10 & -3 & -30 & 60 \\
\hline $2.10-2.19$ & 16 & -4 & -64 & 256 \\
\hline $2.00-2.09$ & 3 & -5 & -15 & 75 \\
\hline $1.90-1.99$ & 4 & -6 & -24 & 144 \\
\hline $1.80-1.89$ & 4 & -7 & -28 & 196 \\
\hline $1.70-1.79$ & 4 & -8 & -32 & 256 \\
\hline $1.60-1.69$ & 4 & -9 & -36 & 324 \\
\hline $1.50-1.59$ & 8 & -10 & -80 & 800 \\
\hline $1.40-1.49$ & 2 & -11 & -22 & 242 \\
\hline $1.30-1.39$ & 1 & -12 & -12 & 144 \\
\hline $1.20-1.29$ & 3 & -13 & -39 & 507 \\
\hline $1.10-1.19$ & 2 & -14 & -28 & 392 \\
\hline $1.00-1.09$ & 0 & -15 & 0 & $\underline{0}$ \\
\hline Totals & 199 & & 24 & 6622 \\
\hline \multicolumn{5}{|c|}{$M=A S M+\frac{(\varepsilon f d)}{N} i$} \\
\hline \multicolumn{5}{|c|}{$M=2.55+\frac{(24)}{199} \cdot 10$} \\
\hline & & & & \\
\hline
\end{tabular}


FREQUENCY DISTRIBUTION OF GPAS FOR 1969 AND 1970 BEAVERTON AND SUNSET HIGH SCHOOL NON-BUSINESS EDUCATION GRADUATES

\begin{tabular}{|c|c|c|c|c|}
\hline Class & $f$ & d & $f d$ & $f d^{2}$ \\
\hline $3.90-3.99$ & 11 & 12 & 132 & 1584 \\
\hline $3.80-3.89$ & 25 & 11 & 275 & 3025 \\
\hline $3.70-3.79$ & 23 & 10 & 230 & 2300 \\
\hline $3.60-3.69$ & 31 & 9 & 279 & 2511 \\
\hline $3.50-3.59$ & 60 & 8 & 480 & 3840 \\
\hline $3.40-3.49$ & 62 & 7 & 434 & 3038 \\
\hline $3.30-3.39$ & 70 & 6 & 420 & 2520 \\
\hline $3.20-3.29$ & 70 & 5 & 350 & 1750 \\
\hline $3.10-3.19$ & 69 & 4 & 276 & 1104 \\
\hline $3.00-3.09$ & 82 & 3 & 246 & 738 \\
\hline $2.90-2.99$ & 78 & 2 & 156 & 312 \\
\hline $2.80-2.89$ & 90 & 1 & 90 & 90 \\
\hline $2.70-2.79$ & 82 & 0 & 0 & 0 \\
\hline $2.60-2.69$ & 82 & -1 & -82 & 82 \\
\hline $2.50-2.59$ & 79 & -2 & -158 & 316 \\
\hline $2.40-2.49$ & 63 & -3 & -189 & 567 \\
\hline $2.30-2.39$ & 72 & -4 & -288 & 1152 \\
\hline $2.20-2.29$ & 67 & -5 & -335 & 1675 \\
\hline $2.10-2.19$ & 55 & -6 & -330 & 1980 \\
\hline $2.00-2.09$ & 74 & -7 & -518 & 3626 \\
\hline $1.90-1.99$ & 60 & -8 & -480 & 3840 \\
\hline $1.80-1.89$ & 36 & -9 & -324 & 2916 \\
\hline $1.70-1.79$ & 31 & -10 & -310 & 3100 \\
\hline $1.60-1.69$ & 27 & -11 & -297 & 3267 \\
\hline $1.50-1.59$ & 34 & -12 & -408 & 4896 \\
\hline $1.40-1.49$ & 27 & -13 & -351 & 4563 \\
\hline $1.30-1.39$ & 22 & -14 & -308 & 4312 \\
\hline $1.20-1.29$ & 13 & -15 & -195 & 2925 \\
\hline $1.10-1.19$ & 7 & -16 & -112 & 1792 \\
\hline $1.00-1.09$ & & -17 & -68 & 1156 \\
\hline Totals & 1506 & & -1385 & 64977 \\
\hline \multicolumn{5}{|c|}{$M=A S M+\frac{(\varepsilon f d)}{N} i$} \\
\hline \multicolumn{5}{|c|}{$M=2.77+\frac{(-1385)}{1506} \cdot 10$} \\
\hline & & & & \\
\hline
\end{tabular}


APPEND IX D

LEVEL OF SIGNIFICANCE

Level of significance for the difference between the business and non-business education students' DAT scores:

$$
\begin{aligned}
t & =\frac{M 1-M 2}{\sqrt{\frac{S 1}{N 1}^{2}+\frac{S 2^{2}}{N 2}}} \\
t & =\frac{62.6-56.35}{\sqrt{\frac{26.65^{2}}{199}+\frac{26.4^{2}}{1506}}} \\
& \sqrt{t}=\frac{62.6-56.35}{t} \\
t & =3.11 \\
& \sqrt{\frac{710.2}{199}+\frac{696.9}{1506}}
\end{aligned}
$$


Level of significance for the difference between the business and non-business education students' GPAS:

$$
\begin{aligned}
t & =\frac{M 1-M 2}{\sqrt{\frac{S 1^{2}}{N 1}+\frac{S 2^{2}}{N 2}}} \\
t & =\frac{2.68-2.56}{\sqrt{\frac{.58}{199}+\frac{.65^{2}}{1506}}} \\
t & =\frac{2.68-2.56}{\sqrt{159}} \\
t & =\sqrt{\frac{3.364}{199}+\frac{4.225}{1506}} \\
& \sqrt{.86}
\end{aligned}
$$

